\title{
leva Bāgante
}

\section{DEGUNA ELPOŠANAS FUNKCIJA UN ESTĒTIKA BĒRNIEM AR VIENPUSĒJU CAUREJOŠU LŪPAS, ALVEOLĀRĀ IZAUGUMA UN AUKSLĒJU ŠĶELTNI}

Promocijas darba kopsavilkums medicinas doktora zinātniskā grāda iegūšanai Specialitāte - mutes, sejas un žoḳ̣u ķirurǵija 


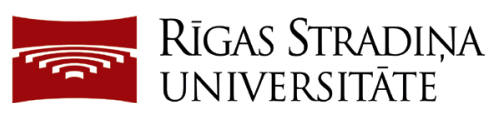

\author{
Ieva Bāgante
}

\title{
DEGUNA ELPOŠANAS FUNKCIJA UN ESTĒTIKA BĒRNIEM AR VIENPUSĒJU CAUREJOŠU LŪPAS, ALVEOLĀRA A IZAUGUMA UN AUKSLĒJU ŠĶELTNI
}

\author{
Promocijas darba kopsavilkums \\ medicīnas doktora zinātniskā grāda iegūšanai
}

Specialitāte - mutes, sejas un žokḷu ķirurğija

Rīga, 2018 
Promocijas darbs izstrādāts Rīgas Stradiṇa universitātes Stomatoloğijas institūtā un Paula Stradiṇa Klīniskās universitātes slimnīcas 45. nodạ̣ā Zobārstniecības un sejas ķirurǵijas centrā.

Darba zinātniskā vadītāja:

Dr. med. profesore Ilze Akota,

Rīgas Stradina universitāte, Latvija

Oficiālie recenzenti:

Dr. habil. med. profesors Aigars Pētersons,

Rīgas Stradiña universitāte, Latvija

Dr. med. profesore Rūta Care, Latvija

$P h D$ Linas Zaleckas,

Viḷnas Universitāte, Lietuva

Promocijas darba aizstāvēšana notiks 2018. gada 12. aprīlī plkst. 15.00 Rīgas Stradiṇa universitātes Medicīnas promocijas padomes atklātā sēdē Rīgā, Dzirciema ielā 16, Hipokrāta auditorijā.

Ar promocijas darbu var iepazīties RSU bibliotēkā un RSU tīmekḷa vietnē: www.rsu.lv.

Promocijas padomes sekretāre:

Dr. med. profesore Ilga Urtāne 


\section{SATURS}

DARBĀ LIETOTIE SAĪSINĀJUMI ................................................... 4

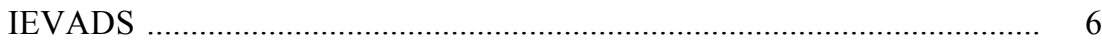

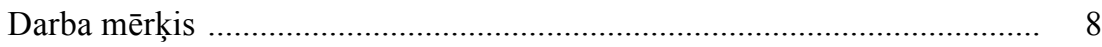

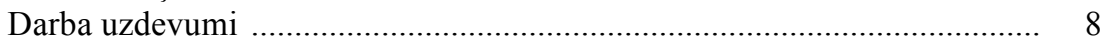

Darba hipotēzes .................................................................................. 9

Darba zinātniskā novitāte un praktiskā vērtība .......................................... 9

1. MATERIĀLS UN METODES ….................................................... 10

1.1. Pētījuma dizains un ètiskie aspekti .............................................. 10

1.2. Pêtījuma kopa ....................................................................... 10

1.3. Metodes apraksts deguna estētikas noteikšanai 2D fotoattēlos .... 13

1.4. Elpošanas funkcijas metodes apraksts ........................................ 15

1.5. 3D stereo-fotogrammetrijas metodes apraksts ............................ 16

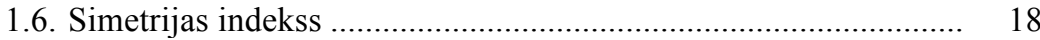

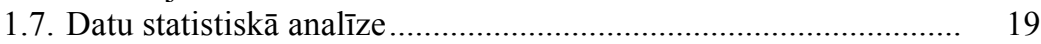

1.8. Ķirự̆iskā ārstēšana .................................................................... 20

2. REZULTĀTI _............................................................................... 21

2.1. Deguna estētikas novērtēšana 2D fotoattēlos............................... 21

2.2. Deguna elpošanas funkcija........................................................ 24

2.3. Deguna un augšlūpas simetrija 3D fotoattēlos............................. 27

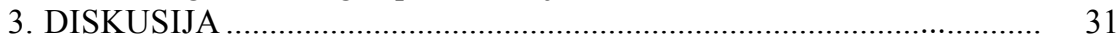

3.1. Pētijuma kopa......................................................................... 31

3.2. Ķirưğiskā ārstēšana .................................................................. 34

3.3. Deguna estētikas un funkcijas novērtēšanas metodes................... 35

3.4. Pētījuma rezultātu interpretācija ................................................... 40

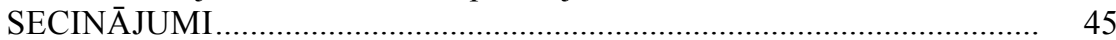

PRAKTISKĀS REKOMENDĀCIJAS _...................................................... 46

LITERATŪRAS SARAKSTS _............................................................. 47

PUBLIKĀCIJAS UN ZIṆOJUMI PAR PĒTĪJUMA TĒMU ..................... 53

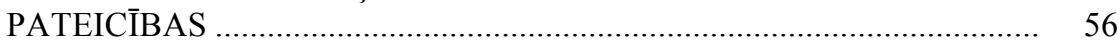




\section{DARBĀ LIETOTIE SAĪSINĀJUMI}

\begin{tabular}{|c|c|}
\hline 2D & divdimensiju \\
\hline $3 \mathrm{D}$ & trīsdimensiju \\
\hline $\mathrm{al}(\mathrm{L})$ & deguna spārns (kreisais) \\
\hline al(R) & deguna spārns (labais) \\
\hline alL-N & deguna sāna garums kreisajā pusē \\
\hline alL-PRN & deguna spārna garums kreisajā pusē \\
\hline alL-Sn & nāss platums kreisajā pusē \\
\hline alR-alL & deguna platums \\
\hline alR-N & deguna sāna garums labajā pusē \\
\hline alR-PRN & deguna spārna garums labajā pusē \\
\hline alR-Sn & nāss platums labajā pusē \\
\hline ANOVA & analysis of variance (variāciju analīze) \\
\hline $\operatorname{ch}(\mathrm{L})$ & lūpu kaktiņš (kreisais) \\
\hline $\operatorname{ch}(\mathrm{M})$ & augšlūpa (viduspunkts) \\
\hline ch(M)lower & apakšlūpa (viduspunkts) \\
\hline $\operatorname{ch}(\mathrm{R})$ & lūpu kaktinšs (labais) \\
\hline chL-cphL & lūpas garums līdz lūpu lokam kreisajā pusē \\
\hline chR-cphR & lūpas garums līdz lūpu lokam labajā pusē \\
\hline CLCSI & Cleft Lip Component Symmetry Index (simetrijas indekss) \\
\hline $\mathrm{cm}^{3} / \mathrm{s}$ & kubikcentimetri sekundē \\
\hline $\mathrm{Cph}(\mathrm{L})$ & lūpu loka augšējais punkts (kreisais) \\
\hline $\mathrm{Cph}(\mathrm{R})$ & lūpu loka augšějais punkts (labais) \\
\hline cphL-chM & lūpas loka attālums līdz viduslīnijai kreisajā pusē \\
\hline cphR-chM & lūpas loka attālums līdz viduslīnijai labajā pusē \\
\hline Dx & labā puse (latīn. dextra) \\
\hline en $(L)$ & endokants (kreisais) \\
\hline en(M) & endokants (viduspunkts) \\
\hline en( $(R)$ & endokants (labais) \\
\hline $\operatorname{ex}(\mathrm{L})$ & eksokants (kreisais) \\
\hline $\operatorname{ex}(\mathrm{R})$ & eksokants (labais) \\
\hline $\mathrm{G}$ & glabella \\
\hline $\mathrm{mm}$ & milimetri \\
\hline $\mathrm{N}$ & nasion \\
\hline NA & nav aprēķināms \\
\hline $\mathrm{nd}(\mathrm{L})$ & nāss augšejais punkts (kreisais) \\
\hline $\mathrm{nd}(\mathrm{R})$ & nāss augšējais punkts (labais) \\
\hline $\mathrm{nl}(\mathrm{L})$ & nāss zemākais punkts (kreisais) \\
\hline $\mathrm{nl}(\mathrm{R})$ & nāss zemākais punkts (labais) \\
\hline nlL-ndL & nāss augstums kreisajā pusē \\
\hline
\end{tabular}




$\begin{array}{ll}\text { nlR-ndR } & \text { nāss augstums labajā pusē } \\ \mathrm{p} & \text { statistiskās ticamības līmenis } \\ \text { P. Stradiņa KUS } & \text { Paula Stradiṇa Klīniskā universitātes slimnīca } \\ \text { Pa } & \text { paskāli } \\ \text { PRN } & \text { pronasale } \\ \text { deguna muguriñas garums } \\ \text { PRN-N } & \text { deguna augstums } \\ \text { PRN-Sn } & \text { Rīgas Stradiña universitāte } \\ \text { RSU } & \text { deguna spārna apakšējais punkts (kreisais) } \\ \text { Sbal(L) } & \text { deguna spārna apakšējais punkts (labais) } \\ \text { Sbal(R) } & \text { baltās lūpas garums kreisajā pusē } \\ \text { SbalL-cphL } & \text { baltās lūpas garums labajā pusē } \\ \text { SbalR-cphR } & \text { deguna pamatnes platums } \\ \text { SbalR-SbalL } & \text { Stomatologijas institūts } \\ \text { SI } & \text { kreisā puse (latīn. sinistra) } \\ \text { Sin } & \text { subnasale } \\ \text { Sn } & \text { kolumellas pamatne (kreisā puse) } \\ \text { Sn0(L) } & \text { kolumellas pamatne (labā puse) } \\ \text { Sn0(R) } & \text { vizuālo analogu skala }\end{array}$




\section{IEVADS}

Lūpu un aukslēju šķeltnes ir biežākā iedzimtā patologiija sejas un žokḷu rajonā. To etiologija ir kompleksa un ietver gan genētiskos, gan ārējās vides faktorus (Krasone et al., 2014). Vienpusējas caurejošas lūpas, alveolārā izauguma un aukslēju šķeltnes gadījumā vienmēr novēro arī deguna deformāciju (Kim et al., 2004). Tā izraisa ievērojamus estētiskus traucējumus un ir iemesls smagām funkcionālām novirzēm, kas jau pirmajās dzīvības dienās un gados negatīvi ietekmē bērna fizisko un garīgo attīstību (Barkāne, 1997). Latvijā iedzimtu šķeltņu biežums vidēji ir 1,2-1,4 uz 1000 dzīvi dzimušajiem bērniem (Akota u. c., 2001). Vidēji Eiropā iedzimtu šķeltņu biežums svārstās no 1,4 līdz 2 uz 1000 dzīvi dzimušajiem bērniem (Peterka et al., 2000).

Vēsturiski šķeltņu deguna deformācijas korekcija tika atlikta, līdz deguna augšana bija pilnībā beigusies (Torre et al., 2000). Pēdējo 20 gadu laikā notikusi lēna filozofijas maiņa par deguna deformācijas korekcijas apjomu un laiku bērniem ar šķeltnēm. Pašlaik arvien populārāks kḷuvis uzskats par deguna deformācijas korekciju primārās lūpas plastikas laikā (Byrd \& Salomon, 2000). Kaut arī šì operācija samazina psihologiskas problēmas, tā neizslēdz deguna deformāciju nākotnē un nepieciešamību pēc atkārtotas korekcijas (Guyuron, 2008).

Tā kā deguns ir novietots sejas centrālajā dạ̦ā, tā izskatam ir ievērojama ietekme kopējā sejas estētikā (He et al., 2009). Deguna deformācija atkarībā no šķeltnes veida un smaguma pakāpes var būt no gandrīz nepamanāmai līdz katastrofālai (van Loon et al., 2010). Ievērojama deguna deformācija var izraisīt psihologiskas problēmas jau bērnībā. Tāpēc Gosain un Fathi (2009) uzskata, ka sekundāra deguna korekcija vienpusējas caurejošas lūpas, alveolārā izauguma un aukslēju šķeltnes gadījumā bieži ir indicēta bērniem pirmsskolas vecumā (6-8 gadi) (Gosain \& Fathi, 2009). 
Deguna operāciju klīnisko rezultātu novērtējums ir komplicēts tā sarežğītās trīsdimensionālās uzbūves dēḷ (Nolst Trenité et al., 1997). Deguna estētikas objektīvai un kvantitatīvai novērtěšanai līdz šim nav aprakstītas vispāratzītas vienotas metodes (Russell et al., 2001). Diskusijas par deguna estētikas novērtēšanas metodēm pacientiem ar lūpu un aukslēju šķeltnēm joprojām ir aktuālas. Literatūrā atrodams daudz dažādu deguna estētikas novērtēšanas metožu. Al-Omari ar kolēgiem (2005), veicot literatūras analīzi, secinājis, lai arī nav nevienas absolūti ticamas metodes, ar kuru varētu novērtēt deguna estētiku, tomēr tās novērtēšana trīsdimensiju (3D) fotoattēlos bija ar visaugstāko ticamību. Tomēr pētījumos visbiežāk tika izmantota deguna estētikas novērtēšana divdimensiju (2D) fotoattēlos, jo metode bija vienkārša, ilgstoši lietota, ar lielu datubāzi, plaši pieejama un êrti lietojama. Tāpat nav noteikti vispāratzīti mērāmie parametri pēc kuriem noteikt deguna estētiku.

Latvijā pētîjums par lūpu un deguna ķirurǵgiskas ārstēšanas rezultātu novērtējumu pacientiem ar iedzimtām šķeltnēm tika veikts 1968. gadā, kad Rīgas Stradiṇa Universitātes (RSU) docente Biruta Barkāne bija aizstāvējusi disertāciju "Deguna un lūpas vēlīnu deformāciju ķirurgiskka ārstēšana sejas šķeltņu gadījumos". Viens no šī darba mērķiem bija pārbaudīt operāciju efektivitāti pie dažādām lūpas un deguna vēlīnām deformācijām pacientiem, kuri operēti no 1900.-1964. gadam ar dažādiem šķelțu veidiem (Баркане, 1968).

Pētījumi par iedzimtām sejas šķeltnēm joprojām ir aktuāli, jo nav vienotas pieejas par šādu deformāciju korekcijas laikiem un metodiku, lai panāktu gan labu funkcionālu, gan estētisku rezultātu. Lai varētu novērtēt deguna un augšlūpas estētiku un deguna elpošanas funkciju bērniem ar vienpusēju caurejošu lūpas, alveolārā izauguma un aukslēju šķeltni, nepieciešamas objektīvas un êrti lietojamas metodes, ar kurām varētu kvalitatīvi un kvantitatīvi noteikt ārstēšanas rezultātus. 


\section{Darba mērḳis}

Izpētīt deguna un augšlūpas estētiku un deguna elpošanas funkciju bērniem ar vienpusēju caurejošu lūpas, alveolārā izauguma un aukslēju šķeltni, ārstētiem RSU Stomatologijas institūta (SI) Lūpu, aukslēju un sejas šķeltṇu centrā. Pamatojoties no iegūtajiem rezultātiem, izstrādāt klīniskas rekomendācijas ieviešanai praktiskajā mutes, sejas un žokļu ķirurğijā.

\section{Darba uzdevumi}

1. Novērtēt deguna estētiku bērniem ar vienpusēju caurejošu lūpas, alveolārā izauguma un aukslēju šķeltni pēc lūpas un deguna plastikas divdimensiju (2D) fotoattēlos ar pielāgoto un modificēto Anastassov un Chipkov (2003) izstrādāto vērtēšanas metodi.

2. Novērtēt deguna estētiku bērniem ar vienpusēju caurejošu lūpas, alveolārā izauguma un aukslēju šķeltni pēc lūpas un deguna plastikas 2D fotoattēlos, izmantojot vizuālo analogu skalu (VAS).

3. Noteikt elpošanas funkciju bērniem ar vienpusēju caurejošu lūpas, alveolārā izauguma un aukslēju šķeltni (pētījuma grupa) pēc lūpas un deguna plastikas, salīdzinot ar kontroles grupu.

4. Izmērīt deguna un augšlūpas simetriju trīsdimensiju (3D) fotoattēlos bērniem ar vienpusēju caurejošu lūpas, alveolārā izauguma un aukslēju šķeltni (pētījuma grupa) pēc lūpas un deguna plastikas un salīdzināt ar kontroles grupu.

5. Izstrādāt klīniskas rekomendācijas bērnu ar vienpusējām caurejošām lūpas, alveolārā izauguma un aukslēju škseltnēm aprūpei. 


\section{Darba hipotēzes}

1. Mazām pētījuma grupām deguna estētikas novērtēšana 2D fotoattēlos ir variabla, bet 3D fotoattēlos pietiekami objektīva.

2. Deguna plastika bērniem ar vienpusēju caurejošu lūpas, alveolārā izauguma un aukslēju šķeltni pirmsskolas vecumā nodrošina gan deguna elpošanas funkciju, gan deguna simetriju.

\section{Darba zinātniskā novitāte un praktiskā vērtība}

Latvijā pacientiem ar vienpusēju caurejošu lūpas, alveolārā izauguma un aukslēju škseltni līdz šim nebija novērtēta deguna estētika un deguna elpošanas funkcija pēc ķirurğiskas ārstēšanas.

Darba pirmajā dal̦ā izmantota modificēta Anastassov un Chipkov (2003) detalizēta klīniska vērtēšanas skala, kura pētījumā pielāgota deguna estētiskai novērtēšanai divdimensiju fotoattēlos. Pētījuma otrajā daļā veikta estētikas un funkcijas kompleksa novērtēšana, pielietojot gan inovatīvu aparatūru un metodi deguna un augšlūpas simetrijas novērtēšanai trīsdimensiju fotoattēlos, gan deguna elpošanas funkcijas noteikšanu ar priekšēju rinomanometriju. Pirmo reizi Latvijā bērnu ar iedzimtu vienpusēju caurejošu lūpas, alveolārā izauguma un aukslēju šķeltni ķirurğiskas ārstēšanas rezultāti salīdzināti ar veseliem bērniem (kontroles grupu).

Lai regulāri noteiktā bērna vecumā varētu ticami novērtēt gan estētiskos, gan funkcionālos ārstēšanas rezultātus pacientiem ar iedzimtu vienpusēju caurejošu lūpas, alveolārā izauguma un aukslēju šķeltni, nepieciešams ieviest jaunas objektīvas metodes klīniskajā praksē. 


\section{MATERIĀLS UN METODES}

\subsection{Pētījuma dizains un ētiskie aspekti}

Pētījums tika veikts RSU SI Lūpu, aukslēju un sejas šķeltņu centrā un P. Stradiņa KUS 45. nodạ̦ā Zobārstniecības un sejas ķirurǵijas centrā. Deguna estētikas novērtējums 2D fotoattēlos bija retrospektīvs. Deguna elpošanas funkcijas novērtējums ar priekšēju rinomanometriju un deguna un augšlūpas simetrijas novērtējums 3D fotoattēlos bija šķērsgriezuma pētījums.

Pētījumam saņemta RSU Ėtikas komitejas aţ̧auja un informētās piekrišanas aptauja no vecākiem un pilngadīgajiem pētījuma dalībniekiem.

\subsection{Pētījuma kopa}

Mērķa populācija - bērni ar iedzimtu nesindromisku vienpusēju lūpas, alveolārā izauguma un aukslēju šķeltni.

Deguna estētikas noteikšanai $2 \mathrm{D}$ fotoattēlos tika veikta pacientu sistemātiskā atlase - visi RSU SI Lūpu, aukslēju un sejas šķeltņu centrāa reǵistrētie bērni ar vienpusēju lūpas, alveolārā izauguma un aukslēju šķeltni, kuriem veikta primāra lūpas un deguna plastika no 1995. gada 1. janvāra līdz 2008. gada 31. decembrim un kuri 2011. gadā bija sasnieguši 3 gadu vecumu. Pēc RSU SI Lūpu, aukslēju un sejas šķelţ̦u centra datu bāzes datiem tie bija 59 bērni.

Deguna elpošanas funkcijas un deguna un augšlūpas simetrijas novērtēšanai 3D fotoattēlos tika veikta pacientu sistemātiskā atlase - visi RSU SI Lūpu, aukslēju un sejas šķeltņu centrā reǵistrētie un Latvijā dzimušie bērni no 1994. gada 1. janvāra līdz 2004. gada 31. decembrim (10-18 gadu vecumā) ar iedzimtu nesindromisku vienpusēju lūpas, alveolārā izauguma un aukslēju 
šķeltni. Pēc RSU SI Lūpu, aukslēju un sejas šķeltņu centra datu bāzes datiem tie bija 62 bērni.

Iekḷaušanas kritēriji:

Bērni ar iedzimtu nesindromisku vienpusēju caurejošu lūpas, alveolārā izauguma un aukslēju šķeltni, kuri:

1. Ir dzimuši Latvijā un reǵistrēti RSU SI Lūpu, aukslēju un sejas šķeltņu centrā.

2. Ir ārstēti ar atbilstošām ārstēšanas metodēm RSU SI Lūpu, aukslēju un sejas škseltņu centrā.

3. Nav diagnosticēti ǵenētiski sindromi.

4. Kuriem ir pieejami 2D fotoattēli pretskata un kolumellas projekcijā 3 vai 5 gadu vecumā vai abos norādītajos vecumos (tikai deguna estētikas noteikšanai $2 \mathrm{D}$ fotoattēlos).

Izslēgšanas kritēriji:

1. Bērni ar iedzimtu vienpusēju nepilnu lūpas, alveolārā izauguma un aukslēju šķeltni vai ar Simonarta kroku.

2. Bērni ar vienpusēju caurejošu lūpas, alveolārā izauguma un aukslēju šķeltni, kuri ir miruši.

3. Bērni ar vienpusēju caurejošu lūpas, alveolārā izauguma un aukslēju šķeltni, kuri ir adoptēti uz ārzemēm vai emigrējuši.

4. Bērni ar vienpusēju caurejošu lūpas, alveolārā izauguma un aukslēju šķeltni, kuri ir dzimuši Latvijā, bet operēti citā valstī.

5. Bērni, kuriem nav pieejami kvalitatīvi fotoattēli ne 3 gadu vecumā, ne 5 gadu vecumā (tikai deguna estētikas noteikšanai 2D fotoattēlos).

Diagnoze tika apstiprināta ar fotoattēliem pirms primāras lūpas un deguna plastikas. Deguna estētikas noteikšanai 2D fotoattēlos pēc izslēgšanas kritērijiem 
pētījumā iekļauti 27 bērni (11 meitenes un 16 zēni) ar vienpusēju caurejošu lūpas, alveolārā izauguma un aukslēju šķeltni, kuriem bija kvalitatīvi 2D fotoattēli pretskata un kolumellas projekcijā trīs gadu vecumā vai piecu gadu vecumā, vai abos norādītajos vecumos. Pētījumā iekļautajiem bērniem šķeltne 20 gadījumos atradās kreisajā pusē, bet 7 gadījumos labajā pusē. No pētījuma izslēgti 32 bērni, no tiem 14 bērni ar vienpusēju nepilnu lūpas, alveolārā izauguma un aukslēju šḳeltni, 4 bērni ar Simonarta kroku, 1 bērns, kurš bija miris nesasniedzot 3 gadu vecumu, 3 bērni, kuri bija adoptēti uz ārzemēm vai emigrējuši līdz 3 gadu vecumam, 10 bērni, kuriem nebija pieejami vai nebija kvalitatīvi 2D fotoattēli ne 3 gadu, ne 5 gadu vecumā.

Deguna elpošanas funkcijas un deguna un augšlūpas simetrijas novērtēšanai $3 \mathrm{D}$ fotoattēlos pēc izslēgšanas kritērijiem pētījumā iekḷauti 35 bērni ar vienpusēju caurejošu lūpas, alveolārā izauguma un aukslēju šķeltni. No iekḷautajiem 35 bērniem uz kontroli atnāca 30 (15 meitenes un 15 zēni) deguna elpošanas funkcijas un simetrijas noteikšanai un salīdzināšanai 3D fotoattēlos (pētījuma grupa). Šķeltne 21 gadījumā atradās kreisajā pusē, bet 9 gadījumos labajā pusē, vidējais bērna vecums bija 14 gadi, robežās no 10-18 gadiem. No pētījuma izslēgti 27 bērni, no tiem 13 bērni ar vienpusēju nepilnu lūpas, alveolārā izauguma un aukslēju šķeltni, 4 bērni ar Simonarta kroku, 5 bērni, kuri bija miruši, 3 bērni, kuri bija adoptēti uz ārzemēm vai emigrējuši, 2 bērni, kuri operēti citā valstī.

Kontroles grupā iekḷauti pirmie 35 veseli bērni 10 gadu vecumā (18 zēni, 17 meitenes), kuri bija atnākuši piedalīties RSU Stomatologiijas institūtā notiekošajā sejas augšanas novērtěšanas pētījumā un kuri piekrita piedalīties arī šajā pētījumā. 


\subsection{Metodes apraksts deguna estētikas noteikšanai 2D fotoattēlos}

Pēc pētījumā iekḷauto 27 bērnu 2D fotoattēlu analīzes un sagatavošanas deguna estētikas novērtēšanai, tika izveidoti 23 fotoattēlu pāri pretskata un kolumellas projekcijā bērniem 3 gadu vecumā un 20 fotoattēlu pāri bērniem 5 gadu vecumā. Fotoattēli tika sagatavoti pēc vienotas sistēmas - melnbalti, izgriezti trīsstūri, kuros redzami tikai deguns un lūpas (skat. 1.1. att.). Visos fotoattēlos šķeltne tika pozicionēta vienā lūpas pusē - sākumā kreisajā, bet pēc tam labajā pusē. Fotoattēlu pāri, kuri sastāvēja no viena bērna pretskata un kolumellas projekcijas 2D fotoattēliem, anonīmi, kodēti, sajauktā secībā tika ievietoti power point prezentācijā.
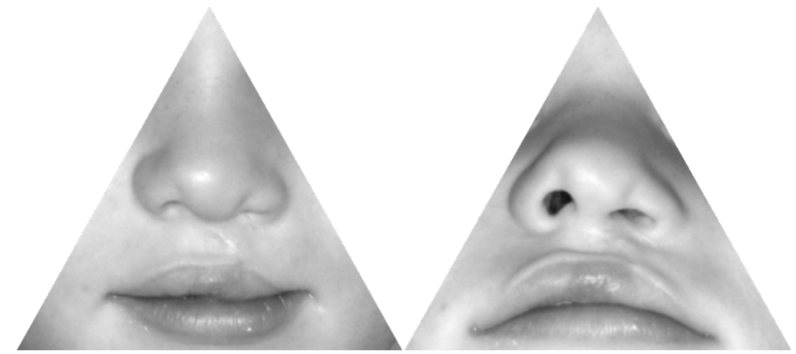

\section{1. att. Deguna estētikas novērtēšanas 2D fotoattēlu pāris 3 gadu vecumā, škseltnei atrodoties kreisajā pusē}

Deguna estētikas novērtēšanai 2D fotoattēlos tika izmantota modificēta un pielāgota Anastassov un Chipkov (2003) izstrādātā deguna estētikas vērtēšanas skala un vizuālo analogu skala (VAS). Pirms vērtēšanas eksperti tika iepazīstināti ar attēliem un sagatavoti vērtēšanai. Katrs attēlu pāris tika novērtēts vienu minūti pēc modificētas Anastassov un Chipkov (2003) izstrādātās klīniskas vērtēšanas skalas, kura īpaši pielāgota deguna deformāciju novērtēšanai 2D fotoattēlos pacientiem ar vienpusēju caurejošu lūpas, alveolārā izauguma un 
aukslēju šķeltni (skat. 1.1. tab.). Šĩ deguna estētikas novērtēšanas skala sastāv no negatīviem punktiem no 0,5-3, kas atspoguḷo deguna deformācijas smaguma pakāpes, jo vairāk punkti tiek atzīmēti konkrētajā 2D fotoattēlu pārī, jo vairāk deformēts ir bērna deguns. Kopumā novērtēšanu veica četras reizes divi novērtētāji. Divas reizes novērtěšana veikta, kad šķeltne atradās kreisajā pusē un divas reizes labajā pusē. Katra novērtēšana veikta ar vienas nedēḷas intervālu.

1.1. tabula

Modificēta Anastassov un Chipkov (2003) deguna estētikas novērtēšanas skala

\begin{tabular}{|c|c|c|c|}
\hline $\mathrm{Nr}$. & Pozīcija & Shematisks attēls & Punkti \\
\hline 1. & Simetrisks deguns & & 0 \\
\hline 2. & Kolumella pārāk īsa & Qp & 0,5 \\
\hline 3. & $\begin{array}{l}\text { Redzama starpsienas } \\
\text { subluksācija vai deviāciia }\end{array}$ & ge & 1 \\
\hline 4. & Plata nāsu pamatne & 20? & 0,5 \\
\hline 5. & Šaura nāsu pamatne & 92 & 0,5 \\
\hline 6. & Kolumellas pamatne pārāk plata & 98 & 0,5 \\
\hline 7. & Kolumellas pamatne pārāk šaura & 98 & 0,5 \\
\hline 8. & Nepietiekoša spārna ieloce & 29 & 0,5 \\
\hline 9. & Pārāk izteikta spārna ieloce & 23 & 0,5 \\
\hline 10. & Nāsu augšējās malas & \multirow{2}{*}{ qes } & 0,5 \\
\hline 11. & Spārna skrimšḷa nepareiza & & 1 \\
\hline 12. & Spārna augsta pozīcija & 23 & 0,5 \\
\hline 13. & Spārna zema pozīcija & 28 & 0,5 \\
\hline 14. & $\begin{array}{l}\text { Saplacināts un hipoplastisks } \\
\text { spārns }\end{array}$ & 20 & 3 \\
\hline 15. & Summa & & \\
\hline
\end{tabular}


Deguna estētikas novērtēšanai 2D fotoattēlu komplektos ar vizuālo analogu skalu (VAS), tika izmantoti vertikāli, bez iedaļu, $100 \mathrm{~mm}$ gari stabiṇi, kuros augšpusē norādīts „simetrisks deguns, bez deformācijas”, apakšā „lielāka deformācija nav iedomājama”. Novērtēšanu veica power point prezentācijā ievietotajos attēlos, katru 10 sekundes. Vērtēšanā piedalījās 4 novērtētāji. Mērījumi veikti vienu reizi attēlos, kur visas šķ̧eltnes pagrieztas uz kreiso pusi un vienu reizi, kur pagrieztas uz labo pusi, abus mērījumus atkārtojot ar vienas nedēlas intervālu.

\subsection{Elpošanas funkcijas metodes apraksts}

Deguna elpošanas funkcijas noteikšanai pētījuma un kontroles grupām tika veikta priekšēja rinomanometrija ar Otopront kombinētu rinomanometrijas un akustiskās rinometrijas ierīci RHINO-SYS (Happersberg otopront GmbH, Vācija). Bērniem ar iedzimtu vienpusēju caurejošu lūpas, alveolārā izauguma un aukslēju škeltni rinomanometrijas izmeklējums veikts ne ātrāk kā 6 mēnešus pēc pēdējās deguna korekcijas (bez un ar dekongestantu (deguna pilieni Xymelin $0,1 \%)$ pēc vispārējiem standartiem). Elpošanas plūsmas smaguma pakāpe tika noteikta pēc Bachmann gradācijas (Bachmann, 1983) (skat. 1.2.tab.).

1.2. tabula

Deguna obstrukcijas gradācijas pakāpes vienai nāsij pēc Bachmann (1983)

\begin{tabular}{|l|l|}
\hline Deguna obstrukcijas pakāpe & Elpošanas plūsma [cm3/s] pie $150 \mathrm{~Pa}$ \\
\hline Nav obstrukcijas & $>500$ \\
\hline Viegla obstrukcija & $300-500$ \\
\hline Vidēja obstrukcija & $180-300$ \\
\hline Smaga obstrukcija & $<180$ \\
\hline
\end{tabular}




\subsection{D stereo-fotogrammetrijas metodes apraksts}

Trīsdimensiju stereo-fotometrisks izmeklējums sejas virsmas topogrāfiskas anatomijas un krāsu tekstūras iegūšanai ar 3dMD face System (3dMD face System; 3dMD LLC, Atlanta, GA). Veicot 3D fotoattēla uzņemšanu, persona tika apsēdināta uz krēsla $90 \mathrm{~cm}$ fiksētā attālumā no kameras dabīgā galvas pozīcijā un ieraduma sakodienā. Bērniem ar vienpusēju caurejošu lūpas, alveolārā izauguma un aukslēju šķeltni 3D fotoattēli uzņemti ne ātrāk kā 6 mēnešus pēc pēdējās deguna korekcijas. Pirms antropometrijas veikšanas, visi 3D fotoattēli tika apstrādāti tā, lai šķeltne atrastos kreisajā pusē. Pēc tam tika atlikti 25 antropometriski punkti un izmērīti 18 lineāri attālumi galvenokārt pamatojoties no Farkas ar kolēgiem (1993) pētījuma ar modifikācijām pēc Hood ar kolēgiem (2004) un van Loon ar kolẹgiem (2010) (skat. 1.2. att., 1.3. tab. un 1.4. tab.).

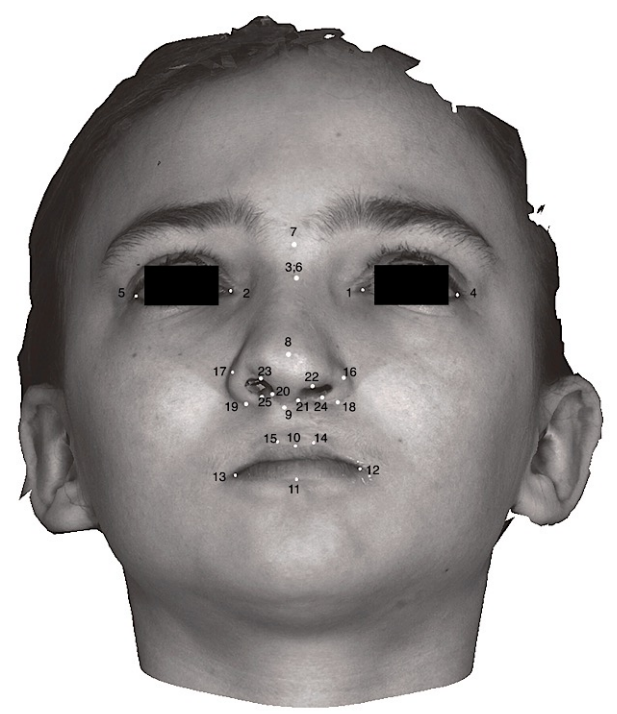

1.2. att. 3D foto ar atliktiem antropometriskiem punktiem 
Antropometriskie punkti 3D fotoattēlos tika atlikti manuāli, izmantojot 3dMD Vultus software programmu (3dMD Vultus Software Platform, 3dMD LLC, Atlanta, USA). Mīksto audu anatomisko punktu atskaites vertikālā plakne Y tika pozicionēta caur glabella un nasion, horizontālā plakne X tika pozicionēta caur labo un kreiso endokantu (Verzé et al., 2014). Lai noteiktu intra-novērtētāja ticamību, visi mērījumi tika veikti divas reizes ar vienas nedēlas intervālu.

1.3. tabula

Antropometriskie punkti un to skaidrojums

\begin{tabular}{|c|c|c|}
\hline $\mathrm{Nr}$. & Antropometriskie punkti & Saīsinājums \\
\hline 1. & Endokants (kreisais) & en $(L)$ \\
\hline 2. & Endokants (labais) & en(R) \\
\hline 3. & Endokants (viduspunkts) & en(M) \\
\hline 4. & Eksokants (kreisais) & $\mathrm{ex}(\mathrm{L})$ \\
\hline 5. & Eksokants (labais) & $\operatorname{ex}(\mathrm{R})$ \\
\hline 6. & Nasion & $\mathrm{N}$ \\
\hline 7. & Glabella & $\mathrm{G}$ \\
\hline 8. & Pronasale & PRN \\
\hline 9. & Subnasale & Sn \\
\hline 10. & Augšlūpa (viduspunkts) & $\operatorname{ch}(\mathrm{M})$ \\
\hline 11. & Apakšlūpa (viduspunkts) & ch(M)lower \\
\hline 12. & Lūpu kaktiṇš (kreisais) & $\operatorname{ch}(\mathrm{L})$ \\
\hline 13. & Lūpu kaktinšs (labais) & $\operatorname{ch}(\mathrm{R})$ \\
\hline 14. & Lūpu loka augšējais punkts (kreisais) & $\mathrm{Cph}(\mathrm{L})$ \\
\hline 15. & Lūpu loka augšējais punkts (labais) & $\mathrm{Cph}(\mathrm{R})$ \\
\hline 16. & Deguna spārns (kreisais) & $\mathrm{al}(\mathrm{L})$ \\
\hline 17. & Deguna spārns (labais) & $\mathrm{al}(\mathrm{R})$ \\
\hline 18. & Deguna spārna apakšejais punkts (kreisais) & Sbal(L) \\
\hline 19. & Deguna spārna apakšējais punkts (labais) & Sbal(R) \\
\hline 20. & Kolumellas pamatne (labā puse) & $\mathrm{Sn} 0(\mathrm{R})$ \\
\hline 21. & Kolumellas pamatne (kreisā puse) & $\mathrm{Sn} 0(\mathrm{~L})$ \\
\hline 22. & Nāss augšējais punkts (kreisais) & $\operatorname{nd}(\mathrm{L})$ \\
\hline 23. & Nāss augšējais punkts (labais) & $\operatorname{nd}(\mathrm{R})$ \\
\hline 24. & Nāss zemākais punkts (kreisais) & $\mathrm{nl}(\mathrm{L})$ \\
\hline 25. & Nāss zemākais punkts (labais) & $\mathrm{nl}(\mathrm{R})$ \\
\hline
\end{tabular}


Antropometriskie attālumi un to skaidrojums

\begin{tabular}{|l|l|l|}
\hline Nr. & Saīsinājums & \multicolumn{1}{c|}{ Apraksts } \\
\hline 1. & cphR-chM & Lūpas loka attālums līdz viduslīnijai labajā pusē \\
\hline 2. & cphL-chM & Lūpas loka attālums līdz viduslīnijai kreisajā pusē \\
\hline 3. & chR-cphR & Lūpas garums līdz lūpu lokam labajā pusē \\
\hline 4. & chL-cphL & Lūpas garums līdz lūpu lokam kreisajā pusē \\
\hline 5. & SbalR-cphR & Baltās lūpas garums labajā pusē \\
\hline 6. & SbalL-cphL & Baltās lūpas garums kreisajā pusē \\
\hline 7. & nlR-ndR & Nāss augstums labajā pusē \\
\hline 8. & nlL-ndL & Nāss augstums kreisajā pusēe \\
\hline 9. & alR-Sn & Nāss platums labajā pusē \\
\hline 10. & alL-Sn & Nāss platums kreisajā pusē \\
\hline 11. & alR-N & Deguna sāna garums labajā pusē \\
\hline 12. & alL-N & Deguna sāna garums kreisajā pusē \\
\hline 13. & alR-PRN & Deguna spārna garums labajā pusē \\
\hline 14. & alL-PRN & Deguna spārna garums kreisajā pusē \\
\hline 15. & alR-alL & Deguna platums \\
\hline 16. & SbalR-SbalL & Deguna pamatnes platums \\
\hline 17. & PRN-N & Deguna muguriñas garums \\
\hline 18. & PRN-Sn & Deguna augstums \\
\hline
\end{tabular}

\subsection{Simetrijas indekss}

Deguna un augšlūpas mērījumiem 3D fotoattēlos tika pielāgots Amaratunga (1988) izmantotais šķelțu lūpas komponenta simetrijas indekss (CLCSI - cleft lip component symmetry index), turpmāk tekstā - simetrijas indekss. Simetrijas indekss tika aprēķināts pēc formulas - attālums šķeltnes pusē pret attālumu veselajā pusē reizinot ar 100. Perfektu simetriju raksturotu vērtība 100, bet vērtība mazāka, vai lielāka par 100 raksturotu asimetrijas pakāpi. Pēc $L i$ ar kolēgiem (2010) ķirurgijijas rezultāts bija izdevies, ja estētikas indekss degunam un augšlūpai bija robežās no 90 līdz 110\% (Li et al., 2010). 


\subsection{Datu statistiskā analīze}

Mērījumiem 2D fotoattēlos ar modificēto un pielāgoto Anastassov un Chipkov (2003) izstrādāto deguna estētikas vērtēšanas skalu tika noteikta metodes ticamības analīze, nosakot Kappa koeficientu un vienprātības procentuālo sakritību. Ja Kappa 0,8-1,0 ticamība l,oti laba, 0,6-0,8 laba, 0,4-0,6 vidēja, 0,2-0,4 slikta, < 0,2 l̦oti slikta (Landis \& Koch, 1977). Vizuālās analogu skalas rezultāti salīdzināti ar ANOVA testu, kur statistiskās ticamības robeža bija $\mathrm{p}<0,05$.

Deguna elpošanas funkcijas datu statistiskai apstrādei izmantotas aprakstošās statistikas metodes. Lai pētījuma grupā noteiktu atšķirību elpošanas plūsmai starp šķeltnes un veselo pusi un kontroles grupā starp labo un kreiso pusi, tika izmantots paired $t$ tests ar statistiskās ticamības robežu $\mathrm{p}<0,05$. Lai noteiktu atšķirību elpošanas plūsmai starp pētījuma grupu un kontroles grupu tika izmantots unpaired $t$ tests ar statistiskās ticamības robežu $\mathrm{p}<0,05$.

Mērījumiem 3D fotoattēlos, lai noteiktu mērījuma kḷūdu tika izmantota Dahlberg formula (Dahlberg, 1940), kur mērījuma kḷūda tika uzskatīta par pieņemamu, ja tā nepārsniedza 3\% no kopējās dispersijas. Lai noteiktu izmērīto attālumu atšksirību starp škseltnes un ne šķeltnes pusi, tika izmantots Wilcoxon signed rank tests, bet Mann-Whitney tests, lai salīdzinātu pētījuma grupu ar kontroles grupu, kur statistiskās ticamības robeža $\mathrm{p}<0,05$. Paired $t$ tests tika izmantots indeksu salīdzināšanai ar vērtību 100, lai noteiktu statistiski ticamu asimetrijas pakāpi starp šķeltnes un veselo pusi pētījuma grupā un labo un kreiso pusi kontroles grupā. Unpaired $t$ tests tika izmantots, lai noteiktu statistiski ticamu atšķirību starp pētījuma grupu un kontroles grupu ar statistiskās ticamības robežu $\mathrm{p}<0,05$. Lai noteiktu saistību starp elpošanas funkciju un deguna simetriju, tika izmantots ANOVA tests, kur statistiskās ticamības robeža bija $\mathrm{p}<0,05$. 


\section{8. Ķirurğiskā ārstēšana}

Visus pētījumā iekļautos bērnus ar vienpusēju caurejošu lūpas, alveolārā izauguma un aukslēju šķeltni bija operējuši divi mutes, sejas un žokļu ķirurgi. Primāra lūpas plastika tika veikta lietojot Millard rotācijas metodi (Millard $J r, 1976$ ). Caur šī dizaina griezienu tika veikta vienlaicīga primāra deguna korekcija, kuras laikā piln̄ibā tika mobilizēta deguna spārna pamatne šķeltnes pusē. Deguna starpsienas skrimšl̦ainās dal̦as repozīcija, bez papildu fiksācijas tika uzsākta kopš 2001. gada 1. janvāra visiem bērniem ar iedzimtu vienpusēju caurejošu lūpas, alveolārā izauguma un aukslēju šķeltni primāras lūpas un deguna plastikas laikā. Sekundāra deguna korekcija tika veikta ar vaļēju pieeju un ietvēra starpsienas un apakšèjā laterālā skrimšļa repozīciju un fiksāciju.

Pētījuma daļā, kurā noteikta deguna estētika 2D fotoattēlos, lūpas plastika tika veikta vidēji 6,3 mēnešu vecumā (diapazonā no 2 līdz 24 mēnešiem). Primāra starpsienas skrimšļainās daļas repozīcija, bez papildu fiksācijas tika veikta 15 bērniem. No pētījumā iekḷautajiem bērniem trīs un piecu gadu vecumā, nevienam netika veikta sekundāra deguna korekcija pirms deguna estētikas novērtēšanas $2 \mathrm{D}$ fotoattēlos.

Pētījuma dạ̦ā, kurā noteikta deguna elpošanas funkcija un deguna un augšlūpas simetrija 3D fotoattēlos, lūpas plastika tika veikta vidēji 6,6 mēnešu vecumā (diapazonā no 3-24 mēnešiem). Sekundāra deguna korekcija pirmsskolas vai agrīnas skolas vecumā tika veikta 26 bērniem. Vidējais vecums sekundārai deguna korekcijai bija 7,8 gadi (robežās 6-10 gadi). Sekundāras deguna korekcijas laikā pirmsskolas vecuma bērniem, piecos gadījumos veikta arī augšlūpas korekcija. Četrpadsmit gadījumos tika veiktas vairākas deguna korekcijas, līdz rezultāts tika uzskatīts par apmierinošu gan no pacientu, gan apkārtējo viedokḷa. Četriem pētījuma pacientiem tika veikta tikai primāra lūpas un deguna plastika, bez sekundāras deguna korekcijas. 


\section{REZULTĀTI}

\subsection{Deguna estētikas novērtēšana 2D fotoattēlos}

Novērtējot deguna estētiku ar pielāgoto un modificēto Anastassov un Chipkov (2003) novērtēšanas skalu, rezultātu summa svārstījās no 0 līdz 3 punktiem. Tādas deformācijas kā "šaura nāsu pamatne", "kolumellas pamatne pārāk šaura", "saplacināts un hipoplastisks spārns" nevienam pacientam netika atzīmēts. Visbiežāk tika atzīmētas "nāsu augšèjās malas deformācija" un "plata nāsu pamatne", bet diemžēl novērtētāju domas šajās pozīcijās visvairāk atšks̄īās (novērtētāju variabilitāte bija visaugstākā) (skat. 2.1. tab. un 2.2. tab.). Tā kā pētījumā iekḷautā grupa bija salīdzinoši maza, tad dažos gadījumos Kappa koeficientu nebija iespējams aprēķināt, jo skaitl̦i bija pārāk mazi, tad jāṇem vērā tikai vienprātības procentuālā sakritība. Tika noteikta intra novērtētāja variabilitāte A un B novērtētājam mērījumiem škseltnei atrodoties kreisajā pusē un labajā pusē (skat. 2.1. tab.). Kā redzams, vietām Kappa ir zem 0,4, kas norāda par zemu vienprātību, bet ir pozīcijas, kur Kappa ir 1, kas norāda par l̦oti labu ticamību. Novērtētāju A un B intra variabilitāte bija līdzīga. Vairākumā novērtējuma pozīciju, Kappa atradās robežās no 0,5-1,0, kas norāda par vidēju līdz ļoti labu ticamību (skat. 2.1. tab.).

Lai noteiktu metodes ticamību starp vairākiem novērtētājiem, tika noteikts Kappa koeficients starp A un B novērtētāju pēc atkārtotiem mērījumiem šķeltnei atrodoties kreisajā pusē un labajā pusē (skat. 2.2. tab.). Mērījumi tika veikti divas reizes ar vienas nedēḷas intervālu. Līdzīgi kā intra novērtētāju Kappa rādītāji, arī šajos mērījumos Kappa ar l̦oti labu ticamību bija pozīcijās "simetrisks deguns”, "šaura nāsu pamatne”, "kolumellas pamatne pārāk plata vai šaura”, “saplacināts un hipoplastisks spārns”. Savukārt pozīcijas, kuru aprakstītās deguna deformācijas pazīmes tika konstatētas un atzīmētas visbiežāk, kā 
“nāsu augšējās malas deformācija" un "plata nāsu pamatne”, Kappa rādītāji ir viszemākie, kas norāda par vienprātības trūkumu starp novērtētājiem.

2.1. tabula

Intra novērtētāja variabilitāte A un B novērtētājam mērījumiem šķeltnei atrodoties kreisajā (sin) pusē un labajā (dx) pusē

\begin{tabular}{|c|c|c|c|c|c|c|c|c|c|}
\hline \multirow[b]{2}{*}{$\mathrm{Nr}$. } & \multirow{2}{*}{$\begin{array}{c}\text { Modificētas } \\
\text { Anastassov un } \\
\text { Chipkov (2003) } \\
\text { novēertēšanas skalas } \\
\text { pozīcija }\end{array}$} & \multicolumn{2}{|c|}{$A \sin$} & \multicolumn{2}{|c|}{$B \sin$} & \multicolumn{2}{|c|}{$A d x$} & \multicolumn{2}{|c|}{$B d x$} \\
\hline & & $\%$ & Kappa & $\%$ & Kappa & $\%$ & Kappa & $\%$ & Kappa \\
\hline 1. & Simetrisks deguns & 100 & 1,0 & 100 & 1,0 & 100 & 1,0 & 100 & 1,0 \\
\hline & Kolumella pārāk īsa & 90,7 & 0,8 & 90,7 & 0,8 & 74,4 & 0,2 & 86,1 & 0,7 \\
\hline & $\begin{array}{l}\text { Redzama starpsienas } \\
\text { subluksācija vai } \\
\text { deviācija }\end{array}$ & 97,7 & 0,9 & 86,1 & 0,6 & 97,7 & 0,9 & 95,4 & 0,8 \\
\hline 4. & Plata nāsu pamatne & 74,4 & 0,5 & 79,1 & 0,6 & 60,5 & 0,1 & 83,7 & 0,6 \\
\hline & Šaura nāsu pamatne & 100 & 1,0 & 100 & 1,0 & 100 & 1,0 & 100 & 1,0 \\
\hline & $\begin{array}{l}\text { Kolumellas pamatne } \\
\text { pārāk plata }\end{array}$ & 100 & 1,0 & 93,0 & 1,0 & 100 & 1,0 & 100 & 1,0 \\
\hline & $\begin{array}{l}\text { Kolumellas pamatne } \\
\text { pārāk šaura }\end{array}$ & 100 & 1,0 & 100 & 1,0 & 100 & 1,0 & 100 & 1,0 \\
\hline & $\begin{array}{l}\text { Nepietiekoša spārna } \\
\text { ieloce }\end{array}$ & 90,7 & 0,8 & 88,4 & 0,8 & 100 & 1,0 & 88,4 & 0,7 \\
\hline & $\begin{array}{l}\text { Pārāk izteikta spārna } \\
\text { ieloce }\end{array}$ & 97,7 & 0,9 & 76,7 & 0,5 & 93,0 & NA* & 95,4 & 0,6 \\
\hline & $\begin{array}{l}\text { Nāsu augšējās malas } \\
\text { deformācija }\end{array}$ & 93,0 & 0,5 & 88,4 & 0,7 & 57,1 & 0,1 & 85,7 & 0,7 \\
\hline & $\begin{array}{l}\text { Spārna skrimšlı̄a } \\
\text { nepareiza pozicija }\end{array}$ & 72,1 & 0,4 & 83,7 & 0,5 & 81,4 & 0,4 & 93,0 & 0,8 \\
\hline 12. & Spārna augsta pozīcija & 100 & 1,0 & 93,0 & 0,6 & 88,4 & 0,4 & 95,4 & 0,6 \\
\hline 13. & Spārna zema pozīija & 86,1 & 0,2 & 97,7 & 0,8 & 95,4 & 0,6 & 95,4 & 0,6 \\
\hline 14. & $\begin{array}{l}\text { Saplacināts un } \\
\text { hipoplastisks spārns }\end{array}$ & 100 & 1,0 & 100 & 1,0 & 100 & 1,0 & 100 & 1,0 \\
\hline 15. & Summa & 46,5 & 0,3 & 30,2 & 0,1 & 53,5 & 0,4 & 58,1 & 0,4 \\
\hline
\end{tabular}

*NA - Kappa nav aprēķināms. Ja Kappa 0,8-1,0 ticamība loti laba, 0,6-0,8 laba, $0,4-0,6$ vidēja, $0,2-0,4$ slikta, $<0,2$ l,oti slikta 
2.2. tabula

Inter novērtētāja variabilitāte A un B novērtētājam pēc atkārtotiem mērījumiem šķeltnei atrodoties kreisajā (sin) pusē un labajā (dx) pusē

\begin{tabular}{|c|c|c|c|c|c|c|c|c|c|}
\hline & Modificētas Anastassov & & n 1 & & n 2 & & $x 1$ & & $x 2$ \\
\hline $\mathrm{Nr}$. & $\begin{array}{c}\text { novērtēšanas skalas } \\
\text { pozīcija }\end{array}$ & $\%$ & Kappa & $\%$ & Kappa & $\%$ & Kappa & $\%$ & Kappa \\
\hline 1. & Simetrisks deguns & 100 & 1,0 & 100 & 1,0 & 100 & 1,0 & 100 & 1,0 \\
\hline 2. & Kolumella pārāk īsa & 74,4 & 0,2 & 79,1 & $\mathrm{NA}^{*}$ & 65,1 & NA & 72,1 & 0,3 \\
\hline & $\begin{array}{l}\text { Redzama starpsienas } \\
\text { subluksācija vai } \\
\text { deviācija }\end{array}$ & 74,4 & 0,2 & 81,4 & 0,4 & 76,7 & NA & 74,4 & NA \\
\hline 4. & Plata nāsu pamatne & 76,7 & 0,5 & 86,1 & 0,7 & 69,8 & 0,3 & 65,1 & NA \\
\hline 5. & Šaura nāsu pamatne & 100 & 1,0 & 100 & 1,0 & 100 & 1,0 & 100 & 1,0 \\
\hline & $\begin{array}{l}\text { Kolumellas pamatne } \\
\text { pārāk plata }\end{array}$ & 93,0 & NA & 100 & 1,0 & 100 & 1,0 & 100 & 1,0 \\
\hline & $\begin{array}{l}\text { Kolumellas pamatne } \\
\text { pārāk šaura }\end{array}$ & 100 & 1,0 & 100 & 1,0 & 100 & 1,0 & 100 & 1,0 \\
\hline & $\begin{array}{l}\text { Nepietiekoša spārna } \\
\text { ieloce }\end{array}$ & 65,1 & 0,2 & 67,4 & NA & 67,4 & NA & 69,8 & NA \\
\hline & $\begin{array}{l}\text { Pārāk izteikta spārna } \\
\text { ieloce }\end{array}$ & 74,4 & 0,1 & 83,7 & 0,1 & 90,7 & 0,1 & 88,4 & 0,1 \\
\hline & $\begin{array}{l}\text { Nāsu augšējās malas } \\
\text { deformācija }\end{array}$ & 69,8 & 0,4 & 65,1 & 0,3 & 64,3 & 0,3 & 64,3 & 0,3 \\
\hline & $\begin{array}{l}\text { Spārna skrimšla } \\
\text { nepareiza pozīcija }\end{array}$ & 79,1 & 0,4 & 74,4 & 0,3 & 79,1 & 0,5 & 81,4 & 0,5 \\
\hline 12. & Spārna augsta pozīcija & 86,1 & NA & 93,0 & NA & 95,4 & 0,6 & 88,4 & NA \\
\hline 13. & Spārna zema pozīcija & 90,7 & 0,6 & 97,7 & 0,7 & 95,4 & 0,6 & 95,3 & NA \\
\hline 14. & $\begin{array}{l}\text { Saplacināts un } \\
\text { hipoplastisks spārns }\end{array}$ & 100 & 1,0 & 100 & 1,0 & 100 & 1,0 & 100 & 1,0 \\
\hline 15. & Summa & 32,6 & 0,2 & 41,9 & 0,2 & 30,2 & 0,1 & 34,9 & 0,2 \\
\hline
\end{tabular}

*NA - Kappa nav aprēķināms. Ja Kappa 0,8-1,0 ticamība ḷoti laba, 0,6-0,8 laba, $0,4-0,6$ vidēja, $0,2-0,4$ slikta, $<0,2$ ḷoti slikta

Novērtēšana ar VAS izrādījās ļoti subjektīva un variabla, gan novērtējot vienam vērtētājam labo un kreiso pusi, gan savstarpēji starp vērtētājiem. VAS intra novērtētāja atšķirīibas $\mathrm{p}$ vērtība visos gadījumos bija $<0,05$, tas nozīmē, ka katru reizi viens un tas pats novērtētājs deguna estētiku bija novērtējis atšķirīgi (skat. 2.1. att.). 


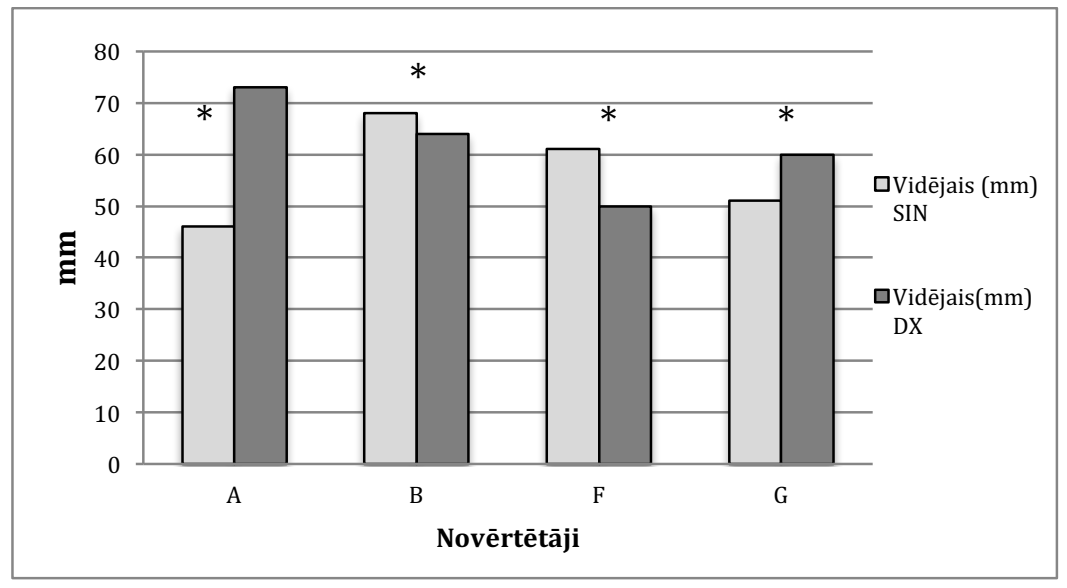

2.1. att. Intra novērtētāju variabilitāte novērtējumam ar VAS šḳeltnei atrodoties labajā (dx) un kreisajā (sin) pusē

* statistiski ticama atšksirība, $\mathrm{p}<0,05$

\subsection{Deguna elpošanas funkcija}

Pētījuma grupas elpošanas plūsmas rādītāju atšķirība pirms un pēc dekongestantu lietošanas, nebija statistiski ticama, tāpēc salīdzinājumam tika izmantotas vērtības tikai pēc dekongestācijas. Vidējā deguna elpošanas plūsma bērniem ar vienpusēju caurejošu lūpas, alveolārā izauguma un aukslēju šķeltni pēc dekongestanta lietošanas caur veselo nāsi bija $330,6 \mathrm{~cm}^{3} / \mathrm{s}$, caur šķeltnes pusi $169,1 \mathrm{~cm}^{3} / \mathrm{s}$ pie $150 \mathrm{~Pa}$, atšķirība starp veselo nāsi un šķeltnes pusi bija statistiski ticama, $p<0,05$. Bērniem, kuriem šķeltne bija lokalizēta labajā pusē bija nedaudz sliktāki elpošanas plūsmas vidējie rādītāji caur šķeltnes pusi, nekā bērniem ar šķeltnes lokalizāciju kreisajā pusē, šī atšķirība nebija statistiski ticama. Pētījuma pacientu elpošanas plūsma diapazonā bez obstrukcijas un viegla obstrukcija pēc Bachmann (Bachmann, 1983) caur veselo nāsi bija 18 gadījumos, bet caur šķeltnes nāsi 7 gadījumos. Vidēja obstrukcija pēc Bachmann tika novērota 
6 gadījumos caur veselo nāsi un 9 gadījumos caur šķeltnes nāsi. Smaga obstrukcija tika novērota 6 gadījumos caur veselo nāsi un 14 gadījumos caur šķeltnes nāsi (skat. 2.2.att.). Četros gadījumos elpošanas plūsma bija sliktāka caur veselo pusi, bet 18 gadījumos sliktāka caur šķeltnes pusi, 8 gadījumos elpošanas plūsma caur abām nāsīm bija vienādā līmenī. Elpošanas plūsmas smaguma pakāpe nebija saistīta ar deguna sekundāras korekcijas laiku vai papildu deguna korekcijām un to skaitu, gan vienā gan otrā gadījumā elpošanas plūsmas smaguma pakāpe bija diapazonā bez obstrukcijas līdz smagai obstrukcijai pēc Bachmann (skat. 2.2. att.).

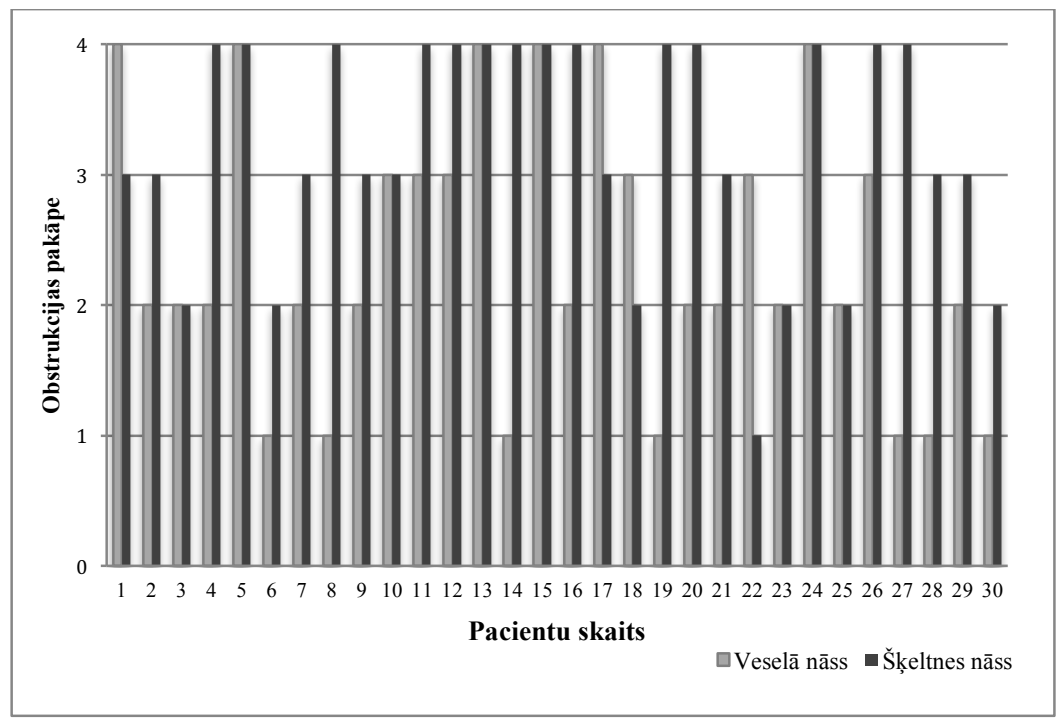

2.2. att. Elpošanas plūsmas obstrukcijas pakāpes pēc Bachmann (1983) 1 - nav obstrukcijas, 2 - viegla obstrukcija, 3 - vidēja obstrukcija, 4 - smaga obstrukcija

Kontroles grupā caur labo pusi elpošana bija $308,4 \mathrm{~cm}^{3} / \mathrm{s}$, caur kreiso pusi $330,4 \mathrm{~cm}^{3} / \mathrm{s}$ pie $150 \mathrm{~Pa}$ pēc dekongestanta lietošanas, šī atšķirība nebija statistiski 
ticama, $p>0,05$. Kontroles grupā elpošanas plūsmas rādītāju atšķirība pirms un pēc dekongestantu lietošanas bija statistiski ticama gan labajai nāsij, gan kreisajai, $\mathrm{p}<0,05$.

Atšķirība starp deguna elpošanu caur šķeltnes pusi pacientiem ar vienpusēju caurejošu lūpas, alveolārā izauguma un aukslēju šķeltni un starp kontroles grupas labo vai kreiso pusi bija statistiski ticama, $\mathrm{p}<0,05$ pēc dekongestanta lietošanas (skat. 2.3. att.). Bet, salīdzinot elpošanas plūsmu caur veselo nāsi pētījuma grupā un labo vai kreiso nāsi kontroles grupā, statistiski ticamas atšķirības nebija. Akustiskās rinomanometrijas dati uzrāda statistiski ticamas atšķirības starp šķeltnes pusi un veselo pusi, kā arī salīdzinājumā ar kontroles grupu.

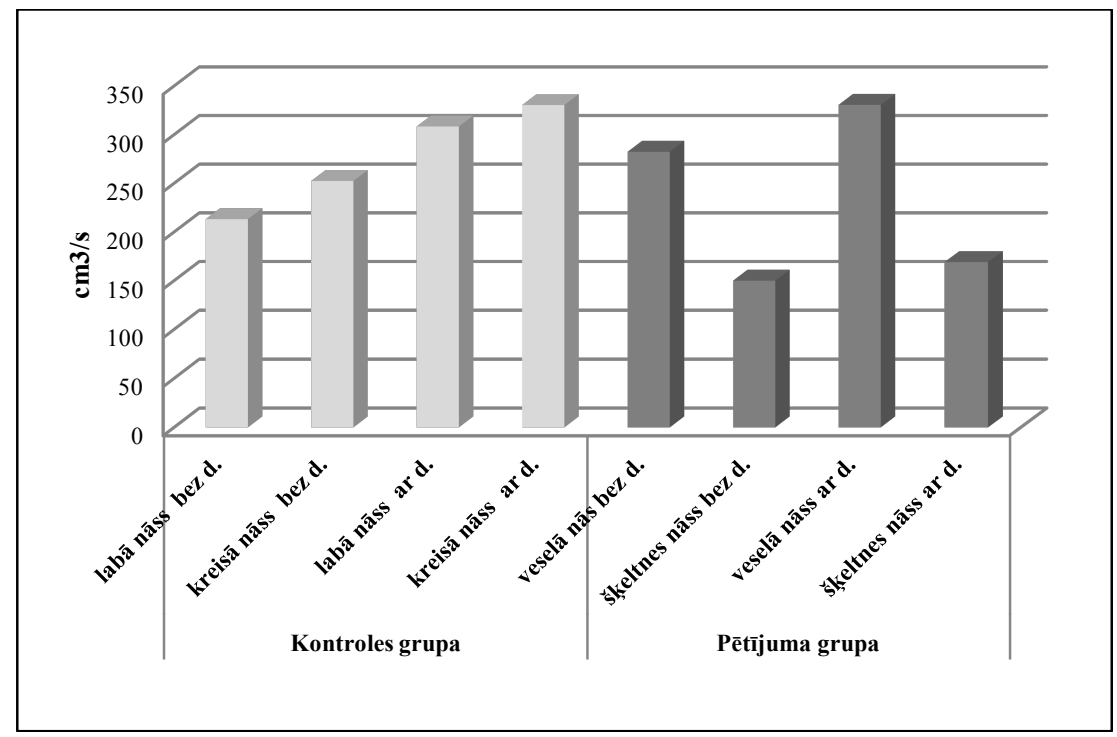

2.3. att. Vidējie elpošanas plūsmas rādītāji pētījuma un kontroles grupā pie $150 \mathrm{~Pa}$

d. - dekongestants (Xymelin 0,1\%) 


\subsection{Deguna un augšlūpas simetrija 3D fotoattēlos}

Mērījumu kḷūda starp pirmo un otro mērījumu reizi 3D fotoattēlos nepārsniedza 3\% no kopējās dispersijas. Tā kā statistiski ticama atšķirība netika pierādīta starp pirmo un otro mērījumu reizi (intra novērtētāja variabilitāte) ne pētījuma grupā, ne kontroles grupā, tad tālākai mērījumu salīdzināšanai tika izmantota pirmā un otrā mērījuma vidējā vērtība. Pētījuma grupā vienīgais mērījums ar statistiski ticamu atšķirību starp šķeltnes un ne šķeltnes pusi bija deguna spārna garums (al-PRN), kurš bija īsāks un vairāk saplacināts šķeltnes pusē $(\mathrm{p}<0,05)$ (skat. 2.4. att.).

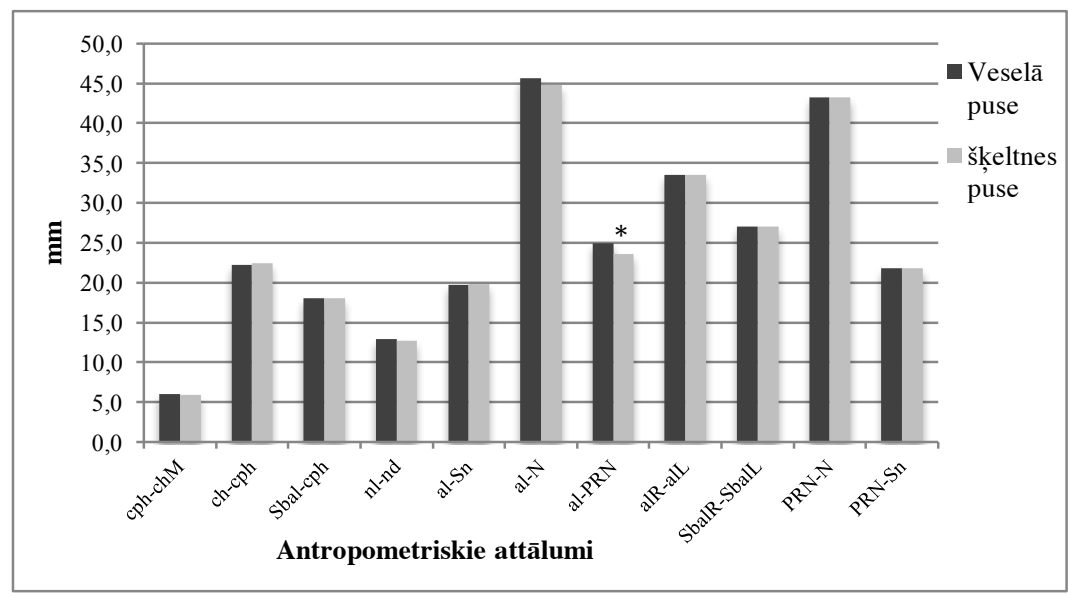

2.4. att. Antropometriskie attālumi pētījuma grupā

* Statistiski ticama atšķirīiba, $\mathrm{p}<0,05$

Atšķirīibas kontroles grupā starp labo un kreiso deguna pusi nebija statistiski ticamas. Atšķirības starp pētījuma un kontroles grupu bija statistiski ticamas visos mērījumu parametros izņemot lūpas garums līdz lūpas locinam 
abās pusēs (chR-cphR, chL-cphL) (skat. 2.5. att.). Apmierinoša deguna un lūpas simetrija pēc ķirurğiskās ārstēšanas tika sasniegta visiem pacientiem.

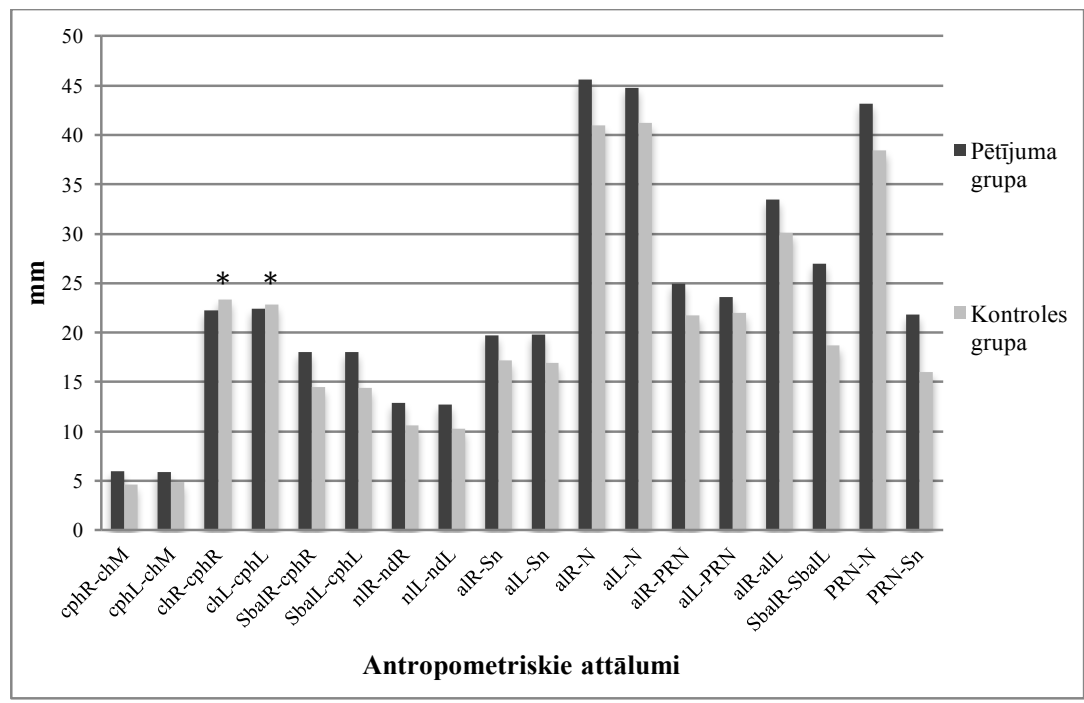

\section{5. att. Antropometriskie attālumi milimetros starp pētījuma un kontroles grupu}

* Nav statistiski ticama atšķirība, $\mathrm{p}>0,05$

Pētījuma grupā simetrijas indeksa atšķirība starp šķeltnes un veselo pusi attiecībā pret 100 (ideāla simetrija) statistiski ticama atšķirība bija starp lūpas loka attālumiem līdz viduslīnijai (cph-cM), deguna garumu sānu pusē (al-N) un deguna spārna garumu (al-PRN) šķeltnes un veselajā pusē. Starp pārējiem mērījumiem statistiski ticamas atšķirības nebija (skat. 2.3. tab.).

Novērtējot ķirurgiijas rezultātu pēc $L i$ ar kolēǵiem (2010), pacientiem ar vienpusēju caurejošu lūpas, alveolārā izauguma un aukslēju šķeltni tika sasniegts labs pēc operācijas rezultāts, jo vidējais simetrijas indekss bija 
robežās no 95 līdz 110\%. Ja estētikas indekss degunam un lūpai ir robežās no 90 līdz 110\%, tad tiek uzskatīts, ka ķirurgíjas rezultāts ir izdevies (Li et al., 2010).

Kontroles grupā simetrijas indeksa statistiski ticama atšķirīiba starp labo un kreiso pusi attiecībā pret 100 bija nāsu augstumam (nl-nd) (skat. 2.3. tab.).

2.3. tabula

\section{Simetrijas indeksa atšķirība starp šķeltnes un veselo pusi pētījuma grupā un starp kreiso un labo pusi kontroles grupā}

\begin{tabular}{|c|c|c|c|c|}
\hline \multirow{2}{*}{ Nr. } & \multirow{2}{*}{ Simetrijas indekss } & \multirow{2}{*}{ Apraksts } & \multicolumn{2}{|c|}{ Simetrijas indeksa vidējā vērtība } \\
\hline & & & Pētījuma grupa & Kontroles grupa \\
\hline & $\frac{\operatorname{cph} L-\operatorname{chM}}{\operatorname{cphR}-\operatorname{chM}} \times 100$ & $\begin{array}{l}\text { Lūpas loka attālums } \\
\text { lìdz viduslīnijai }\end{array}$ & $110^{*}$ & 103 \\
\hline & $\frac{\operatorname{chL}-\operatorname{cph} L}{\operatorname{chR}-\operatorname{cphR}} \times 100$ & $\begin{array}{l}\text { Lūpas garums līdz } \\
\text { lūpu lokam }\end{array}$ & 100 & 98 \\
\hline & $\frac{\text { SbalL }-\mathrm{cphL}}{\text { SbalR }-\mathrm{cphR}} \times 100$ & Baltās lūpas garums & 97 & 102 \\
\hline & $\frac{n l L-n d L}{n l R-n d R} \times 100$ & Nāsu augstums & 98 & $96^{*}$ \\
\hline & $\frac{\mathrm{alL}-\mathrm{Sn}}{\mathrm{alR}-\mathrm{Sn}} \times 100$ & $\begin{array}{l}\text { Nāsu platums pie } \\
\text { pamatnes }\end{array}$ & 100 & 100 \\
\hline & $\frac{\operatorname{alL}-N}{\operatorname{alR}-N} \times 100$ & $\begin{array}{l}\text { Deguna sāna } \\
\text { garums }\end{array}$ & $98^{*}$ & 101 \\
\hline & $\frac{\text { alL }- \text { PRN }}{\text { alR }- \text { PRN }} \times 100$ & $\begin{array}{l}\text { Deguna spārna } \\
\text { garums }\end{array}$ & $95^{*}$ & 102 \\
\hline
\end{tabular}

*Statistiski ticama atšķirība $\mathrm{p}<0,05$

Salīdzinot simetrijas indeksus starp pētījuma un kontroles grupu, statistiski ticama atšķirīiba bija starp baltās lūpas garumu (Sbal-cph), deguna garumu sānu pusē (al-N) un deguna spārna garumu (al-PRN) (skat. 2.4. tab.). 


\section{Pētijuma un kontroles grupas simetrijas indeksa atšksirības}

\begin{tabular}{|c|c|c|c|}
\hline $\mathrm{Nr}$. & Simetrijas indekss & Apraksts & $\begin{array}{c}\text { Unpaired } \mathrm{t} \text { tests } \\
(\mathrm{p}<0,05)\end{array}$ \\
\hline 1 & $\frac{\mathrm{cphL}-\mathrm{chM}}{\operatorname{cphR}-\operatorname{chM}} \times 100$ & $\begin{array}{l}\text { Lūpas loka attālums } \\
\text { līdz viduslīnijai }\end{array}$ & $\mathrm{p}=0,15$ \\
\hline 2 & $\frac{\operatorname{chL}-\operatorname{cphL}}{\operatorname{chR}-\operatorname{cphR}} \times 100$ & $\begin{array}{l}\text { Lūpas garums līdz lūpu } \\
\text { lokam }\end{array}$ & $p=0,22$ \\
\hline 3 & $\frac{\text { SbalL }-\mathrm{cphL}}{\text { SbalR }-\mathrm{cphR}} \times 100$ & Baltās lūpas garums & $p=0,03$ \\
\hline 4 & $\frac{\mathrm{nlL}-\mathrm{ndL}}{\mathrm{nlR}-\mathrm{ndR}} \times 100$ & Nāsu augstums & $\mathrm{p}=0,29$ \\
\hline 5 & $\frac{\mathrm{alL}-\mathrm{Sn}}{\mathrm{alR}-\mathrm{Sn}} \times 100$ & $\begin{array}{l}\text { Nāsu platums pie } \\
\text { pamatnes }\end{array}$ & $\mathrm{p}=0,48$ \\
\hline 6 & $\frac{\text { alL }-N}{\operatorname{alR}-N} \times 100$ & Deguna sāna garums & $\mathrm{p}=0,003$ \\
\hline 7 & $\frac{\text { alL }- \text { PRN }}{\text { alR }- \text { PRN }} \times 100$ & Deguna spārna garums & $\mathrm{p}=0,002$ \\
\hline
\end{tabular}

Tika noteikta saistība starp elpošanas funkciju un deguna estētiku pacientu grupā ar vienpusēju caurejošu lūpas, alveolārā izauguma un aukslēju šķeltni, statistiski ticama saistība netika pieradīta. Bet elpošanas funkcija caur veselo nāsi bija atkarīga no kopējā deguna platuma (alR-alL) $(\mathrm{p}=0,04)$, jo platāks bija deguns, jo sliktāka bija elpošana, bet elpošanas funkciju caur šķeltnes pusi deguna platums neietekmēja. Savukārt elpošanas plūsmai caur šķeltnes pusi bija statistiski ticama saistība ar deguna muguriņas garumu $(\mathrm{PRN}-\mathrm{N})(\mathrm{p}=0,04)$. Jo garāka bija deguna muguriņa, jo elpošana bija labāka caur šķeltnes pusi, bet elpošanas plūsmu caur veselo nāsi tas neietekmēja. 


\section{DISKUSIJA}

\subsection{Pētījuma kopa}

Lūpu un aukslēju šķeltnes ir biežākā iedzimtā patologija sejas un žokḷu rajonā. Iedzimti sejas šķeltņu veidi un smaguma pakāpes ir variablas. Pacientus ar vienpusēju caurejošu lūpas, alveolārā izauguma un aukslēju šķeltni visplašāk izmanto pētījumos, jo pareizas diagnozes gadījumā ir apmēram vienāda deformācija, protams, šķeltnes platums var būt atšķirīgs. Tāpēc, lai varētu novērtēt ķirurǵiskās ārstēšanas rezultātus pēc iespējas objektīvāk, tika nolemts abās pētījuma daḷās iekḷaut tikai vienpusējas caurejošas lūpas, alveolārā izauguma un aukslēju šķeltnes, pie kurām vienmēr novēro tipisku deguna deformāciju. Šo šķelț̣u ķirurgisiskā ārstēšana ir sarežğīta un grūti panākt gan labu estētisku gan funkcionālu rezultātu. Tā kā šķeltne ir vienpusēja, novēro izteiktu deguna un augšlūpas asimetriju.

Pirmajā pētījuma daḷā, deguna estētikas novērtēšanai 2D fotoattēlos tika iekļauti 27 bērni, tomēr vairāku bērnu 2D fotoattēli 3 vai 5 gadu vecumā bija sliktā kvalitātē vai neprecīzā projekcijā un deguna estētikas novērtēšanai nebija derīgi. Statistiski apstrādājot datus, saskarāmies ar grūtībām tos interpretēt mazo grupu dēḷ. Sākotnēji pētījuma pirmās daļas mērķis, bija salīdzināt deguna estētikas rezultātus bērniem, kuriem veikta tikai primāra lūpas un deguna korekcija ar bērniem, kuriem papildus veikta deguna starpsienas skrimšḷainās dalıas repozīcija primāras lūpas un deguna korekcijas laikā. Tā kā deguna estētikas novērtēšanas metode $2 \mathrm{D}$ fotoattēlos uzrādīja variablus ticamības rezultātus, tad salīdzināt grupas nebija iespējams, jo rezultāti nebūtu ticami.

Otrajā pētījuma dạ̦ā tika iekļauti 35 bērni ar iedzimtu nesindromisku vienpusēju caurejošu lūpas, alveolārā izauguma un aukslēju šķeltni vecumā no 10 līdz 18 gadiem, no kuriem 30 (86\% atsaucība) atnāca uz kontroli un tika 
izmeklēti pēc pētījuma protokola. Visu šķeltṇu veidu dzimstības biežums Latvijā ir aptuveni 1,2-1,4 uz 1000 dzīvi dzimušiem bērniem katru gadu, no kuriem tikai $36 \%$ ir lūpu un aukslēju šķeltnes (Akota et al., 2001). Savukārt vienpusējas caurejošas lūpas, alveolārā izauguma un aukslēju šķeltnes biežums ir vēl mazāks. Tāpēc, lai varētu nodrošināt pietiekoši lielu pētījuma grupu un dati varētu tikt statistiski apstrādāti ar ticamiem rezultātiem, tika izvēlēts pacientu vecuma diapazons no 10-18 gadiem. Bell ar kolēgiem (2014) norāda, ka desmit gadi ir labs robežvecums, kad ir jānovērtē bērna sejas asimetrijas apjoms, kas var ietekmēt tālāko ārstēšanas plānu. Ar desmit gadus veciem bērniem ir iespējama laba komunikācija un sadarbība dažādiem izmeklējumiem, kā 3D stereofotogrammetrija un aktīva priekšēja rinomanometrija. Savā darbā nesaskarāmies ar grūtībām bērniem veikt kvalitatīvus priekšējas rinomanometrijas vai 3D foto izmeklējumus. Augšêjā vecuma robeža 18 gadi tika izvēlēta, jo līdz 18 gadiem bērniem tiek pabeigtas šķeltņu deformāciju korekcijas ar ikgadēju kontroli RSU SI Lūpu, aukslēju un sejas šķeltņu centrā. Divdimensiju fotoattēlu novērtēšanas sadạ̣ā iekļautie bērni lielākā daḷa bija tie paši, kuri iekḷauti novērtēšanai 3D fotoattēlos. Tā kā dzimušie bērni pēc 2004. gada nebija sasnieguši 10 gadu vecumu, tad tos nevarēja iekḷaut 3D pētījumā, bet, lai palielinātu grupu, tika iekḷauti 1994. gadā dzimušie bērni. Kā redzams pētījumā, desmit gadu laikā no 1994.-2004. gadam Latvijā piedzimuši tikai 35 bērni ar vienpusēju caurejošu lūpas, alveolārā izauguma un aukslēju šķeltni no kuriem 10 bērni dzimuši 1994. gadā, savukārt tikai pa vienam bērnam ar vienpusēju caurejošu lūpas, alveolārā izauguma un aukslēju šķeltni bija piedzimuši 2002. un 2004. gadā. Mercado ar kolẹgiem (2011) norāda, ka optimāls pacientu skaits multicentru pētījumam būtu nepieciešams vismaz 30-40 dalībnieku no katra centra. Savukārt Bugaighis ar kolēgiem (2014) norāda, ka pat Lielbritānijāa veiktajā pêtījumā bija nepieciešams paplašināt iekḷauto pacientu vecuma diapazonu līdz pieciem gadiem, lai varētu nodrošināt pietiekoši lielu pētījuma 
grupu, kas ir ierasta parādība pētîjumos pacientiem ar dažādām iedzimtām šķeltnēm (Bugaighis et al., 2014a; Bugaighis et al., 2014b).

Kontroles grupā iekḷauti 35 bērni 10 gadu vecumā. Desmit gadu vecums tika izraudzìts, jo tā ir apakšējā robeža bērnu vecumam pētījuma grupāa kā arī 2014. gadā RSU Stomatologijas Institūtā tika uzsākts starptautisks sejas augšanas novērtěšanas pētījums, kuram tika nejauši atlasīti veseli bērni 10 gadu vecumā. Bija iespējams no šî pêtījuma iesaistīt pirmos 35 bērnus kā kontroles grupu. Kontroles grupas atlases lielums tika pielīdzināts pētījuma grupas atlases lielumam - 35 bērni. Kontroles grupu ar veseliem bērniem ir sarežḡîti atrast gan no sociālā, gan no ētiskā viedokḷa, bet īpaši, ja jāveic kādi izmeklējumi, kuriem nepieciešama aktīva bērna līdzdalība, piemēram, aktīva priekšēja rinomanometrija. Literatūras izpētē par deguna estētikas novērtēšanas metodēm, no 143 atlasītajiem rakstiem, tikai 23 rakstos kā kontroles grupa tika izmantoti veseli bērni dažādos vecumos. Pārsvarā šiem bērniem tika veikti $2 \mathrm{D}$ foto (McComb \& Coghlan, 1996; Kyrkanides et al., 1996; Kim et al., 2004; Daelemans et al., 2006; Russell et al., 2009; Meazzini et al., 2010; Fudalej et al., 2012; Russell et al., 2014) vai 3D foto (Duffy et al., 2000; Hood et al., 2003; Hood et al., 2004; Ayoub et al., 2011; Zreaqat et al., 2012; Bell et al., 2014; Bugaighis et al., 2014a; Bugaighis et al., 2014b; Dadáková et al., 2016; Wu et al., 2016), vienā gadījumā tika veikts video ieraksts (Trotman et al., 2007), vienā gadījumā sejas ğipša veiduḷi (Russell et al., 2000), vienā gadījumā klīniska izmeklēšana (Oosterkamp et al., 2007) un divos gadījumos jau esoši CT dati pēc sejas traumām (Miyamoto \& Nakajima, 2010; Miyamoto et al., 2012).

Šajā pētījumā izmantotā kontroles grupa bija unikāla ar to, ka bērniem tika veikti ne tikai 3D foto, bet arī deguna funkcijas novērtējums ar priekšēju rinomanometriju. 


\section{2. Ķirurğiskā ārstēšana}

Pēdējo 20 gadu laikā, ievērojamu uzman̄ibu ir saņēmusi primāra deguna korekcija primāras lūpas plastikas laikā. Torre ar kolēgiem (2000) uzskata, ka agrīna deguna korekcija nodrošina simetriskāku deguna skrimšlı augšanu (Torre et al., 2000). Arī Byrd un Salomon (2000) uzskata, ka primāra deguna korekcija pacientiem ar šķeltnes izraisītu deguna deformāciju rada simetriskāku degunu un labāku vispārējo izskatu agrīnā dzīves periodā, kas ievērojami samazina psiholoǵisko traumu agrīnos skolas gados (Byrd \& Salomon, 2000). Tomēr Guyuron (2008) uzsver, kaut arī agrīna ķirurǵija samazina psihologiskās problēmas, tā neizslēdz iespējamu deguna deformāciju nākotnē un nepieciešamību pēc papildu deguna korekcijām (Guyuron, 2008). Šobrīd liela dạ̧a deguna deformācijas tiek korig̣ētas primāras lūpas plastikas laikā. Arī RSU SI Lūpu, aukslēju un sejas šķeltņu centrā, pēdējo desmitu gadu laikā liela uzmanība tikusi pievērsta deguna starpsienas skrimšlainās daļas korekcijai primāras lūpas un deguna plastikas laikā. Mēs esam ievērojuši, ka pēc starpsienas novietošanas pareizā pozīcijā lūpas plastikas laikā, deguns aug simetriskāks un nav bijusi nepieciešama sekundāra deguna korekcija pirmsskolas vecumā. Nepieciešami daudzi gadi un lielāks pacientu skaits, lai pierādītu, ka agrīna starpsienas repozīcija izraisa simetriskāku deguna augšanu un iespējams mazāku operāciju skaitu atbilstoša rezultāta sasniegšanai.

Mūsdienu sabiedrībā arvien lielāka uzmanība tiek pievērsta cilvēka izskatam un estētikai. Skola daudziem bērniem ir pirmā iestāde, kur satiekas ar citiem bērniem un sākas socializēšanās process. Izsmiešana un ķircināšana ir ierasta parādība īpaši bērniem ar iedzimtām sejas šķeltnēm (Lorot-Marchand et al., 2015). Gosain un Fathi (2009) uzskata, ka sekundāra deguna korekcija pie vienpusējas caurejošas lūpas, alveolārā izauguma un aukslēju šķeltnes bieži ir indicēta bērniem pirmsskolas vecumā (6-8 gadi). Šajā vecumā ievērojami pieaug 
pacientu sociālā saskarsme un viņi sāk sajust ievērojamu spiedienu no vienaudžiem, kas veido šo bērnu pašapziņu (Gosain \& Fathi, 2009). RSU SI Lūpu, aukslēju un sejas šķeltņu centrā pacientiem ar vienpusēju caurejošu lūpas, alveolārā izauguma un aukslēju šķeltni pie ievērojamas deguna deformācijas tiek veikta sekundāra deguna korekcija jau pirmsskolas vai agrīnā skolas vecumā (6-10 gadi).

\subsection{Deguna estētikas un funkcijas novērtēšanas metodes}

Estētika nav vienkārši novērtējama ar objektīviem mērījumiem (Russell et al., 2009). Sejas formas novērtēšanas metodes varētu iedalīt divās grupās objektīvās metodes, kur tiek lietoti mērījumi un subjektīvās novērtēšanas metodes, kur tiek lietotas vērtēšanas sistēmas, kas pamatojas no sejas apskates secinājumiem un dažiem papildu punktiem (Yamada et al., 1999). Tā kā deguna estētikas novērtēšana 2D fotoattēlos joprojām rakstos ir visbiežāk aprakstītā metode, ir plaši pieejama, ekonomiski izdevīga un ar lielu datubāzi, tā tika izmantota arī šajā darbā. Kopš Eurocleft 1996-2000 publicētā projekta, 2D fotografěšana ir noteikta kā standartprocedūra datu uzkrāšanai, lai vēlāk būtu iespējama datu salīdzināšana starp Eiropas šķeltņu centriem (Shaw et al., 2001). Tika nolemts veikt retrospektīvu deguna estētikas noteikšanu 2D fotoattēlos. Deguna estētikas novērtēšana 2D fotoattēlos izrādījās laikietilpīga, jo bija nepieciešama iepriekšēja materiāla sagatavošana un novērtētāju sagatavošana, lai nodrošinātu maksimāli standartizētus apstākḷus vairākas nedēḷas pēc kārtas. Līdz ar to pētījuma laikā bija nepieciešams piesaistīt vairākus pētījuma dalībniekus, kuri piedalījās fotoattēlu anonīmā sajaukšanā un novērtěšanā, lai būtu iespējama inter novērtētāja variabilitātes noteikšana. Deguna estētikas novērtējums pie šķeltnēm ir komplicēts, tāpēc 2D fotoattēlos tika iekḷautas divas novērtēšanas metodes - ar pielāgoto un modificēto Anastassov un Chipkov (2003) izstrādāto 
detalizēto vērtēšanas skalu un ar vizuālo analogu skalu (VAS). Anastassov un Chipkov (2003) izstrādātā klīniska vērtēšanas skala īpaši pielāgota deguna estētikas novērtēšanai 2D fotoattēlos. Šāda pielāgota Anastassov un Chipkov (2003) skala tika izmantota arī Baltic Cleft Network multicentru pētījumā. Baltic Cleft Network multicentru pētījuma rezultāti vēl nav zināmi. Arī Zaleckas ar kolēǵiem (2011) savā pētījumā izmantoja līdzīgu skalu, pēc kuras tika novērtēta lūpas un deguna estētika. Pētījuma pirmajā dal̦ā saskarāmies ar nekvalitatīvām 2D fotogrāfijām, kuras bija neprecīzā projekcijā, izplūdušas, vai nebija pieejamas. Arī Mercado ar kolēǵiem (2011) veicot multicentru pētījumu, konstatēja, ka nevienā centrā veicot 2D fotografěšanu nelieto galvas stabilizētāju, lai standartizētu galvas pozīciju fotoattēla uzņemšanas laikā. Līdz ar to nevar objektīvi salīdzināt ķirurğijas rezultātus starp vairākiem centriem. Daudzos centros netiek veiktas fotogrāfijas kolumellas projekcijā, kas ir ļoti svarīga deguna estētikas novērtēšanai (Mercado et al., 2011).

Diskusijas par deguna estētikas novērtēšanas metodēm pacientiem ar lūpu un aukslēju škseltnēm joprojām ir aktuālas. Literatūrā atrodamas daudz un dažādas novērtēšanas metodes, kas norāda, ka neviena nav nevainojama. Vairākos pētījumos deguna estētiskajai novērtēšanai tika lietotas vairākas mērījumu sistēmas un metodes vienlaicīgi. Literatūras analīzē, ko veica Al-Omari ar kolēgiem (2005) tika secināts, ka nav atrasta neviena nevainojama metode ar kuru varētu novērtēt deguna estētiku. Tomēr kā viena no daudzsološākajām metodēm deguna estētikas novērtěšanai tika atzīti 3D fotoattēli (Al-Omari et al., 2005). Pēdējo gadu tendences deguna estētikas novērtēšanā ir sejas lāzerskenēšana ar trīsdimensionālu datorizētu anatomisko punktu un leņ̧̧u novērtēšanu, kas ir objektīvāka un piẹ̦auj izmantot mazāku pētījuma grupu. Daudzi autori norādīja, ka tālāka 3D analīze ar vairāk pacientiem ļaus veikt plašāku un sistemātiskāku analīzi, novērtējot ķirurğiskās tehnikas rezultātus, lai varētu uzlabot sejas simetriju (Stauber et al., 2008). Vairāki autori 
norādīja, ka 3D stereo-fotogrammetrija bija neinvazīva, precīza un labi arhivējama metode, lai novērtētu sejas formu un ķirurgisiskās pārmaiņas. Deguna simetriju varēja kvantitatīvi un precīzi izmērīt ar šo ierīci (Devlin et al., 2007; Mori et al., 2005). Tomēr jāatzīmē, ka šīs metodes izmantošana ir tehnologiiski dārgāka un atsevišķos reǵionos nav pieejama (Russell et al., 2011). N̦emot vērā jaunās tehnoloǵijas plusus, pieejamību un pieredzi deguna estētikas novērtēšanā 2D fotoattēlos, pêtījuma otrajā daļā tika nolemts izmantot 3D stereo-fotometrisku izmeklējumu sejas virsmas topogrāfiskas anatomijas un krāsu tekstūras iegūšanai, lai novērtētu deguna un augšlūpas simetriju bērniem ar vienpusēju caurejošu lūpas, alveolārā izauguma un aukslēju šķeltni. Šì iekārta ir vienkārša, ērti lietojama, pacientiem draudzīga, ne invazīva, ātra un var tikt lietota bērniem.

Literatūrā nav arī vienprātības par mērāmajiem parametriem, lai aprakstītu sejas un deguna morfoloǵiju. Par spīti daudz un dažādiem mērījumiem un antropometriskiem punktiem, kuri tika lietoti sejas estētiskai novērtēšanai pacientiem ar lūpu un aukslēju šķeltnēm (Bagante \& Akota, 2015), tomēr daži mērījumi un punkti tika lietoti gandrīz visos pētījumos, piemēram, degungala punkts, deguna spārnu punkti, nāsu augstums (Farkas et al., 1993; Duffy et al., 2000; Yamada et al., 2002; Ferrario et al., 2003; Hood et al., 2004; Devlin et al., 2007; Weinberg et al., 2009; van Loon et al., 2010; Ayoub et al., 2011; Zreaqat et al., 2012). Šie biežāk lietotie antropometriskie punkti arī tika izvēlēti šajā pētījumā galvenokārt pamatojoties no Farkas ar kolēǵiem (1993) pētījuma ar modifikācijām pēc Hood ar kolēǵiem (2004) un van Loon ar kolẹgiem (2010). Tā kā antropometrisko punktu atlikšana 3D fotoattēlos ir samērā laikietilpīgs process, tika izvēlēts pēc iespējas mazāks antropometrisko punktu skaits, bet lai tas būtu pietiekošs deguna un augšlūpas simetrijas noteikšanai un izmantojams klīnikā rutīnā. Līdzīgi kā van Loon ar kolēǵiem (2010), arī mēs sastapāmies ar grūtībām precīzi atlikt punktus subnazālā rajonā, jo nāsis bieži bija kḷūdu rajons, sarežğītās anatomijas dēḷ un kameras nespējas dēḷ uzṇemt tumšas ejas perfekti. 
Lai varētu standartizēt punktu atlikšanu, automatizēts punktu atlikšanas rādītājs būtu noderīgs. Tik tiešām šādas automatizētas punktu atlikšanas metodes ir atrodamas rakstos, bet to pielietošana praksē joprojām nav populāra. Piemēram, Mishima ar kolēǵiem (2002) izmantoja precīzu kvantitatīvu metodi, lai mērītu deguna formu uz ǵipša veiduḷiem, anatomiskos punktus atliekot pusautomātiski. Šo, pēc autoru domām, īpaši precīzo kontakt tipa 3D koordināšu mērǐšanas aparātu izmantoja pieciem pacientiem (Mishima et al., 2002). Pigott R. W. un Pigott B. B. (2010) izveidoja SymNose programmu, lai efektīvi novērtētu deguna simetriju 2D fotoattēlos. Abas šiss metodes varētu būt daudzsološas, bet pagaidām ir eksperimentālā stadijā. Antropometrisko punktu atlikšanas mērījumu kḷūda nepārsniedza 3\% no kopējās variācijas un sakrita ar iepriekš ziņotiem rezultātiem kā van Loon ar kolēgiem (2010), kas secinājuši, ka neliela mērījumu kḷūda atliekot antropometriskos punktus neizraisa statistiski nozīmīgu mērījumu atšķirību.

Protams, bez estētikas ḷoti svarīga ir arī elpošanas funkcija, kuru vislabāk būtu novērtēt kopā, kā Huempfner-Hierl ar kolēgiem (2009) pētījumā, kur tika novērtēta gan elpošanas funkcija ar aktīvu priekšēju rinomanometriju, rinorezistometriju un akustisko rinometriju, gan deguna estētika, nosakot 57 antropometriskos leņķus un līnijas izejot no 54 antropometriskiem punktiem 2D fotogrāfijās 3 pozīcijās (Huempfner-Hierl et al., 2009). Šajā pētījumā iekḷāvām gan elpošanas funkcijas noteikšanu, gan deguna simetrijas mērījumus 3D fotoattēlos. Atšķirīibā no Huempfner-Hierl ar kolēgiem (2009) pētījuma, mūsu pētījumā tika noteikta deguna simetrija 3D fotoattēlos un tika izmantota kontroles grupa elpošanas funkcijas un deguna simetrijas salīdzināšanai. Cohen ar kolēǵiem (2003) norāda, ka pārsteidzoši maza uzmanība tiek pievērsta deguna deformācijas funkcionālajiem aspektiem un funkcionālajam iznākumam pēc rekonstruktīvajām operācijām, kaut arī ir labi zināms, ka ievērojams pacientu skaits ar vienpusēju caurejošu lūpas, alveolārā izauguma un aukslēju šķeltni cieš 
no deguna elpcel̦u obstrukcijas, kam var būt nozīmīga ietekme deguna fiziolog̣ijai un pacientu dz̄̄ves kvalitātei (Cohen et al., 2003). Rinomanometrija ir biežāk lietotā tehnika, kuru lieto, lai noteiktu deguna kvantitatīvo funkciju, aţ̦aujot mērīt deguna rezistenci un minimālo deguna šķērsgriezuma laukumu (Fukushiro \& Trindade, 2005). Savukārt Andre ar kolēgiem (2009), analizējot uz pierādījumiem balstītus rakstus, secināja, ka joprojām nav pierādīta korelācija starp rinomanometriju un indivīda subjektīvo elpošanas traucējumu sajūtu (Andre et al., 2009). Biežākā deguna elpceļu obstrukcija ir starpsienas deviācija. Tā kā starpsienas deviācija ir bieža anatomiska variācija arī veseliem indivīdiem, bieži tiek diskutēts cik lielā mērā starpsienas deviācija ir klīniski nozīmīga, kas izraisa deguna elpceḷu obstrukciju. Tas nozīmē, ka daudziem cilvēkiem ar starpsienas novirzi nav apgrūtināta elpošana caur degunu (Kim et al., 2014). Lai gan šajā jomā nav vienotas nostājas, tomēr vairāki autori rinomanometriju veica pacientiem pirms un pēc, vai tikai pēc deguna korekcijas, secinot, ka rinomanometrija ir samērā objektīva metode, lai kvantitatīvi noteiktu deguna elpošanas funkciju (Sandham \& Murray, 1993; Dusková et al., 2002; Trindade et al., 2009; Huempfner-Hierl et al., 2009). Mani ar kolēgiem (2010) uzsver, ka svarīgi ir ne tikai objektīvie mērījumi, bet arī indivīda subjektīvās sūdzības (Mani et al., 2010). To novērojām arī savā pētījumā, jo daudziem pacientiem ar vienpusēju caurejošu lūpas, alveolārā izauguma un aukslēju šķeltni nebija izteiktu sūdzību par elpošanas funkcijas traucējumiem, lai gan rinomanometrijas dati uzrādīja obstrukcijas pazīmes. Savukārt Kunkel ar kolēgiem (1997) uzsver, ka pacientiem ar šķeltnēm, kuriem ir jāveic daudzi nekomfortabli izmeklējumi ilgstošas multidisciplināras ārstēšanas laikā īpaši svarīgi ir lietot neinvazīvas izmeklēšanas metodes, kā rinomanometrija. Savāa darbā nesaskarāmies ar grūtībām veikt rinomanometrijas izmeklējumus bērniem ar vienpusēju caurejošu lūpas, alveolārā izauguma un aukslēju šķeltni un kontroles grupas bērniem. Bērni viegli saprata un izpildīja uzdevumu. 


\subsection{Pētījuma rezultātu interpretācija}

Pētījuma rezultātos darbā ar pielāgoto Anastassov un Chipkov (2003) skalu, rezultātu summa svārstījās no 0 līdz 3 punktiem. Visbiežāk tika atzīmētas "nāsu augšējās malas deformācija" un "plata nāsu pamatne", bet to variabilitāte bija visaugstākā. Viena novērtētāja atšķirīiba starp divām novērtēšanas reizēm (intra novērtētāja variabilitāte) bija samērā zema, tātad ar labiem ticamības rādītājiem, bet atškirīiba starp vairākiem novērtētājiem bija ar lielāku inter novērtētāja variabilitāti, kas norāda par metodes subjektīvo dabu. Domājams, ka pētījuma pirmās daļas iekḷauto pacientu skaits un iespējamās $2 \mathrm{D}$ fotoattēlu nepilnības ietekmējušas statistisko ticamību. Lai gan novērtētāji pirms novērtēšanas tika sagatavoti un iepazīstināti ar pielāgoto Anastassov un Chipkov (2003) izstrādāto deguna estētikas novērtēšanas skalu, tomēr atsevišķas pozīcijas varētu tikt interpretētas atšķirīgi. Pētījumos, kuros bija lielāks pacientu skaits, deguna estētikas novērtējums 2D fotoattēlos ar dažādām metodēm uzrādīja labus ticamības rādītājus, piemēram, Pitak-Arnnop ar kolēgiem (2011) apsekoja 50 pacientus. Savukārt Anastassov un Chipkov (2003) deguna un lūpas estētiku novērtēja klīniski uz pacientiem, kas izslēdza iespējamo fotoattēlu kḷūdu. Kā arī Anastassovs mērījumus veica viens pats, vienu reizi, izslēdzot inter un intra novērtētāja variabilitāti.

Novērtēšana ar VAS izrādījās l̦oti subjektīva un variabla, gan novērtējot vienam vērtētājam labo un kreiso pusi, gan savstarpēji starp vērtētājiem. VAS vērtējumā rezultātu ticamību ietekmē tikai cilvēciskais faktors, jo tā balstās pēc "patīk", "nepatīk" principa. Tāpēc pētījumos to izmanto samērā reti un bieži kopā ar vēl kādu estētiskās novērtēšanas metodi. Šì metode ir laba, ja jānovērtē nespeciālista viedoklis, piemēram, pašu pacientu novērtējums, kā to savā pētījumā ir veicis Sinko ar kolēgiem (2005), kur VAS izmantota, lai salīdzinātu

pacientu pašnovērtējumu ar ķirurgu novērtējumu (Sinko et al., 2005). 
Arī Oosterkamp ar kolēgiem (2007) izmantoja VAS, lai pacienti paši novērtētu savu izskatu un funkciju. Oti ar kolēgiem (2014) izmantoja VAS, lai novērtētu deguna estētiku pacientu vecāki, personas no malas un ķirurgi. Ir pētījumi, kuros VAS ir uzrādījis labus statistiski ticamus rezultātus (Bongaarts et al., 2008; Desmedt et al., 2015; Stebel et al., 2016). Domājams, ka vizuālo analogu skala varētu tikt izmantota nosakot pašu pacientu un vecāku apmierinātību ar pēc operācijas rezultātiem, jo tās lietošana ir ērta, lēta un viegli saprotama.

Pētījuma rinomanometrijas rezultāti saskanēja ar literatūrā aprakstītajiem pêtījumiem, kuros salīdzināta šķeltņu pacientu elpošana ar kontroles grupu. Elpošanas plūsma pacientiem ar vienpusēju caurejošu lūpas, alveolārā izauguma un aukslēju šķeltni bija vājāka, nekā veseliem bērniem (Kunkel et al., 1997; Fukushiro \& Trindade, 2005; Mani et al., 2010). Rinomanometrijas pētījumi uzrāda palielinātu gaisa plūsmas rezistenci šķeltnes pusē dēḷ starpsienas deviācijas un samazinātu gaisa plūsmas rezistenci veselajā pusē. Tomēr četros gadījumos bērniem ar vienpusēju caurejošu lūpas, alveolārā izauguma un aukslēju šķ̣eltni elpošanas plūsma caur šķeltnes pusi bija labāka nekā caur ne šķeltnes pusi, par spīti starpsienas novirzei. Šo terminu sauc par paradoksālu deguna obstrukciju. To izskaidro kā samazinātu gaisa plūsmu kontralaterālajā pusē, ko izraisa obstrukcija no kompensatoras apakšèjās konhas hipertrofijas (Ridgway et al., 2011). Kā arī traucēta elpošanas plūsma varētu būt saistīta ne tikai ar starpsienas stāvokli, bet arī ar citām otorinolaringologiskām orgānu patologijāām. Reiser ar kolēǵiem (2011) norāda, ka pacientiem ar šķeltnēm deguna elpošanas funkcijas traucējumus izraisa vairāki iemesli kā starpsienas deviācija, hipertrofētas gliemežnīcas, deguna polipi, mugurējās konhas deficīts, adenoīdu audi, mandeles, šauras un/ vai samazinātas nāsis vai intranazālas striktūras. Pēc rinomanometrijas rezultātiem, bērniem ar elpošanas traucējumiem iespējams būtu jāparedz papildus deguna elpošanu koriǵējošas operācijas, bet nav zināms cik lielā mērā tās spētu uzlabot deguna elpošanu. 
Cohen ar kolēgiem (2003) secinājuši, ka labāki elpošanas funkcijas un estētiskie rezultāti tika sasniegti tiem pacientiem, kuriem bija mazāks operāciju skaits. To izskaidro ar audu kontraktūru un rētaudu relatīvi mazu audu elasticitāti elpošanas laikā (Cohen et al., 2003). Tāpat arī Cohen ar kolēǵiem (2003) norāda, ka pacientiem ar vienpusēju caurejošu lūpas, alveolārā izauguma un aukslēju šķeltni pie deguna korekcijas ir nepieciešams ņemt vērā iepriekšèjās operācijas, rētošanās procesu, kas var radīt jatrogēnas deformācijas. Mūsu pētījumā netika pierādīta tieša saistība starp deguna elpošanas plūsmu un operāciju skaitu.

Pētījuma rezultāti antropometriskajos mērījumos 3D fotoattēlos parādīja, ka atšşirība bērniem ar vienpusēju caurejošu lūpas, alveolārā izauguma un aukslēju šķeltni starp šķeltnes un veselo pusi nebija statistiski ticama, izņemot deguna spārna garumam (al-PRN), kas norāda, ka tika sasniegta apmierinoša deguna simetrija pēc sekundārām deguna korekcijām pirmsskolas vecumā un ar̄̄ tiem bērniem, kuriem sekundāra deguna korekcija tika uzskatīta, ka nav nepieciešama. Kontroles grupā atšķirība starp labo un kreiso deguna pusi nebija statistiski ticama, tātad varētu uzskatīt, ka deguns bija simetrisks. Atškirīiba starp pētījuma grupu un kontroles grupu bija statistiski ticama visās antropometriskajās distancēs izṇemot lūpas garumam līdz lūpu lociṇam abās pusēs. Iemesls šādai atšķirībai varētu būt vecuma, auguma un dzimuma atšķirības. Pētījuma grupas pacientu vidējais vecums bija 14 gadi, robežās no 1018 gadiem, savukārt kontroles grupai vidējais vecums bija 10 gadi. Pacientu sadalījums pēc dzimuma bija samērā līdzvērtīgs gan pētījuma grupā (15 zēni un 15 meitenes), gan kontroles grupā (18 zēni un 17 meitenes). Mūsu rezultāti sakrīt arī ar citu autoru publicētiem pētījumiem (Duffy et al., 2000; Yamada et al., 2002; Ferrario et al., 2003; Hood et al., 2004; Ayoub et al., 2011; Okawachi et al., 2011; Zreaqat et al., 2012).

Lai arī statistiski ticama atšķirība pētījuma grupā starp šķeltnes un veselo pusi bija tikai starp deguna spārna garumu, tomēr simetrijas indekss uzrādīja 
statistiski ticamu asimetrijas pakāpi gan deguna spārna garumam (al-PRN), gan arī deguna sānu garumam (al-N) un lūpas loka attālumam līdz viduslīnijai (cph-cM). Tāpat arī kontroles grupā tika novērota simetrijas indeksa statistiski ticama asimetrija nāsu augstumam (nl-nd), kas netika uzrādīta analizējot deguna nāsu augstuma attālumus absolūtos skaițos. Interesanti, ka pētījuma grupā, bija panākta labāka nāsu augstuma simetrija nekā kontroles grupā bērniem bez iedzimtas lūpas un aukslēju šķeltnes. Tas varētu norādīt, ka simetrijas indekss precīzāk nosaka simetriju, tas ir matemātisks mākslīgi izveidots indekss. Tomēr kā raksta Bell ar kolēgiem (2014) tas, ka seja nav pilnībā simetriska jau ir vispār pieņemts fakts. Kā arī piln̄ībā simetriska seja nav estētiska, tā secinājuši Peck H. un Peck S. (1970) savā darbā novērtējot sejas simetriju sava laika skaistuma karalienēm, profesionālām modelēm un citām skaistām sievietēm. Autori seju pa viduslīniju pārdalīja uz pusēm un savienoja abas labās puses kopā izveidojot seju un abas kreisās puses kopā. Novērtējot visas trīs sejas - oriğinālo un abas mākslīgās, secināja, ka tieši neliela sejas asimetrija raksturo estētiski pievilcīgu seju (Peck H. \& Peck S., 1970). Tomēr simetrijas indekss labi noder, lai salīdzinātu pētījuma un kontroles grupas deguna un lūpas simetriju, jo pastāv gan vecuma, gan auguma variācijas, kas nepiel̦auj tiešu antropometrisko attālumu salīdzināšanu. Kā arī simetrijas indekss palīdz noteikt tipiskākās operāciju rezultātu novirzes pacientiem ar šķeltnēm un varētu palīdzēt novērtēt ķirurgisko operāciju rezultātus. $L i$ ar kolēǵiem (2010) veiktajā literatūras analīzē konstatējuši, ka vairāki autori veikuši pētījumus ar veseliem cilvēkiem un secinājuši, ka neliela sejas asimetrija ir iedzimts fenomens un absolūta simetrija nav raksturīga. Viṇi arī secinājuši, ka veseliem cilvēkiem lietotais simetrijas indekss ir robežās no 90 līdz 110\% un šis diapazons tika uzskatīts par simetrisku seju. Ja pacientiem ar šķeltnēm šis simetrijas indekss degunam un lūpai bija robežās no 90 līdz 110\%, tad tika uzskatīts, ka ķirurğijas rezultāts ir izdevies (Li et al., 2010). Ja ņem vērā $L i$ ar kolẹgiem (2010) piedāvāto 
simetrijas indeksa interpretāciju, tad mūsu pētījumā iesaistītajiem pacientiem ar vienpusēju caurejošu lūpas, alveolārā izauguma un aukslēju šķeltni bija izdevies ķirurğijas rezultāts, jo vidējais simetrijas indekss bija robežās no 95 līdz 110\%. Kontroles grupas vidējais simetrijas indekss bija robežās no 96 līdz 103\%.

Russell ar kolēǵiem (2009) norāda, ka nav skaidrs vai mainīgo lielumu statistiski nozīmīga atšķirība ir arī ar klīniski svarīgu nozīmību. Viena no klīniski nozīmīgajām vadlīnijām varētu tikt uzskatīta pamatojoties no $L u$ (1965) ziņojuma, ka asimetrijas lielākas par 3\% ir klīniski pamanāmas (Russell et al., 2009). Savukārt Othman ar kolēgiem (2014) savā darbā pirmie piedāvā, ka klīniski nozīmīga asimetrija, kas izteikta milimetros ir lielāka vai vienāda par $5 \mathrm{~mm}$. Tas nozīmēe, ka klīniski var noteikt asimetriju pacientiem ar vienpusēju caurejošu lūpas, alveolārā izauguma un aukslēju šķeltni, ja tā ir lielāka vai vienāda par $5 \mathrm{~mm}$, salīdzinot ar veseliem indivīdiem (Othman et al., 2014).

Estētika varētu būt vairāku sejas pazīmju akumulācijas interpretācija un, iespējams, ka joprojām estētika nav izmērāma ar specifiskiem objektīviem mērījumiem pacientiem ar vienpusēju caurejošu lūpas, alveolārā izauguma un aukslēju šķeltni (Russell et al., 2009). Deguna elpceḷu obstrukcijas pakāpes ir dažādas un tām nav tiešas korelācijas ar deguna deformācijas smaguma pakāpi (Cohen et al., 2003). To novērojām arī šajā pētījumā, kad netika pierādīta pārliecinoša saistība starp deguna simetriju 3D fotoattēlos un elpošanas funkciju. 


\section{SECINĀJUMI}

1. Deguna estētikas novērtējums ar modificēto Anastassov un Chipkov (2003) vērtēšanas skalu bija ar augstu gan intra, gan inter novērtētāju variabilitāti. Šìs vērtēšanas skalas lietošana 2D fotoattēlos izvēlētajai pacientu grupai bija subjektīva un nebija lietojama grupu salīdzināšanai.

2. Deguna estētikas novērtēšana 2D fotoattēlos ar vizuālo analogu skalu izvēlētajai pacientu grupai bija subjektīva metode.

3. Pacientiem ar vienpusēju caurejošu lūpas, alveolārā izauguma un aukslēju šķeltni pēc rinoplastikas elpošanas plūsma caur veselo pusi vidēji bija ar vieglu obstrukciju, bet caur šķeltnes pusi ar smagu obstrukciju. Kontroles grupā elpošanas plūsma vidēji caur labo un kreiso nāsi bija ar vieglu obstrukciju. Rinomanometrija bija ērta un objektīva metode deguna funkcijas noteikšanai bērniem no 10 gadu vecuma.

4. Vērtējot 3D fotoattēlus, deguna un augšlūpas simetrija tika atjaunota bērniem ar vienpusēju caurejošu lūpas, alveolārā izauguma un aukslēju šķeltni pēc deguna korekcijām pirmsskolas vecumā, kaut arī simetrija starp pētījuma un kontroles grupu atšķīīās. Simetrijas indekss palīdzēja salīizināt pētījuma un kontroles grupas deguna un augšlūpas asimetriju.

5. Deguna un augšlūpas novērtēšana $3 \mathrm{D}$ fotoattēlos ar piedāvāto antropometrisko punktu apjomu bija ērta un precīza metode, lai novērtētu pēc operācijas rezultātus izvēlētajai pacientu grupai, bet deguna estētikas novērtējums 2D fotoattēlos ar izvēlētajām novērtēšanas metodēm uzrādīja subjektīvus rezultātus. Turpmāk deguna simetrijas noteikšanai būtu nepieciešams izmantot $3 \mathrm{D}$ fotoattēlus. 


\section{PRAKTISKĀS REKOMENDĀCIJAS}

1. Bērniem ar vienpusēju caurejošu lūpas, alveolārā izauguma un aukslēju šķeltni pēc operācijas rezultātu novērtēšanai rekomendējams veikt 3D fotografēšanu rutīnā no 10 gadu vecuma.

2. Pētījumā lietotie antropometriskie punkti un attālumi rekomendējami lietot ikdienas darbā klīnikā, lai novērtētu deguna un augšlūpas simetriju.

3. Bērniem ar vienpusēju caurejošu lūpas, alveolārā izauguma un aukslēju šķeltni rekomendējams veikt deguna elpošanas funkcijas noteikšanu ar priekšēju rinomanometriju rutīnā no 10 gadu vecuma. 


\section{IZMANTOTĀ LITERATŪRA}

1. Akota, I., Barkāne, B. un Grasmane, N. 2001. Iedzimto sejas šķeltņu biežuma rādītāji Latvijā no 1960. līdz 1997. gadam. ZRaksti/LMA. 166-170.

2. Barkāne, B. 1997. Lūpu un aukslēju škselțu izplatība un to radītie traucējumi. Zobārstniecības raksti. 15(2), 16-18.

3. Ayoub, A., Garrahy, A., Millett, D., Bowman, A., Siebert, J. P., Miller, J. and Ray, A. 2011. Three-dimensional assessment of early surgical outcome in repaired unilateral cleft lip and palate: part 1. Nasal changes. The Cleft Palate-Craniofacial Journal. 48, 571-577.

4. Al-Omari, I., Millett, D. T. and Ayoub, A. F. 2005. Methods of assessment of cleftrelated facial deformity: a review. The Cleft Palate-Craniofacial Journal. 42(2), 145-156.

5. Amaratunga, N. A. de S. 1988. A comparison of Millard's and LeMesurier's methods of repair of the complete unilateral cleft lip using a new symmetry index. Journal of Oral and Maxillofacial Surgery. 46(5), 353-356.

6. Anastassov, Y. and Chipkov, C. 2003. Analysis of nasal and labial deformities in cleft lip, alveolus and palate patients by a new rating scale: preliminary report. Journal of Cranio-Maxillo-Facial Surgery. 31(5), 299-303.

7. Andre, R. F., Vuyk, H. D., Ahmed, A., Graamans, K. and Nolst Trenite, G. J. 2009. Correlation between subjective and objective evaluation of the nasal airway. A systematic review of the highest level of evidence. Clinical Otolaryngology. 34, 518-525.

8. Bachmann, W. 1983. Clinical functional diagnosis of obstructed nasal respiration. HNO. 31(9), 320-326.

9. Bagante, I. and Akota, I. 2015. Cleft-related nose deformation evaluation and measurement methods. Literature review. Stomatologija. 17(3), 75-83.

10. Bell, A., Lo, T. W. R., Brown, D., Bowman, A. W., Siebert, J. P., Simmons, D. R., Millett, D. T. and Ayoub, A. F. 2014. Three-dimensional assessment of facial appearance following surgical repair of unilateral cleft lip and palate. The Cleft PalateCraniofacial Journal. 51(4), 462-471.

11. Byrd, H. S. and Salomon, J. 2000. Primary correction of the unilateral cleft nasal deformity. Plastic and Reconstructive Surgery. 106(6), 1276-1286.

12. Bongaarts, C. A. M., Prahl-Andersen, B., Bronkhorst, E. M., Spauwen, P. H. M., Mulder, J. W., Vaandrager, J. M. and Kuijpers-Jagtman, A. M. 2008. Effect of infant orthopedics on facial appearance of toddlers with complete unilateral cleft lip and palate (Dutchcleft). The Cleft Palate-Craniofacial Journal. 45(4), 407-413.

13. Bugaighis, I., Mattick, C. R., Tiddeman, B. and Hobson, R. 2014a. 3D asymmetry of operated children with oral clefts. Orthodontics \& Craniofacial Research. 17(1), 27-37.

14. Bugaighis, I., Mattick, C. R., Tiddeman, B. and Hobson, R. 2014b. 3D facial morphometry in children with oral clefts. The Cleft Palate-Craniofacial Journal. 51(4), 452-461.

15. Cohen, M., Smith, B. E. and Daw, J. L. 2003. Secondary unilateral cleft lip nasal deformity: functional and esthetic reconstruction. The Journal of Craniofacial Surgery. 14(4), 584-593. 
16. Dadáková, M., Cagáňová, V., Dupej, J., Hoffmannová, E., Borský, J. and Velemínská, J. 2016. Three-dimensional evaluation of facial morphology in pre-school cleft patients following neonatal cheiloplasty. Journal of Cranio-Maxillo-Facial Surgery. 44(9), 1109-1116.

17. Daelemans, A., Leloup, T., Decaesteker, C. and De Mey, A. 2006. New digital method for quantitative assessment of nasal morphology. Scandinavian Journal of Plastic and Reconstructive Surgery and Hand Surgery. 40(6), 335-344.

18. Dahlberg, G. 1940. Statistical Methods for Medical and Biological Students. London: George Allen \& Unwin Ltd. 122-132.

19. Desmedt, D. J., Maal, T. J., Kuijpers, M. A., Bronkhorst, E. M., Kuijpers-Jagtman, A. M. and Fudalej, P. S. 2015. Nasolabial symmetry and esthetics in cleft lip and palate: analysis of 3D facial images. Clinical Oral Investigations. 19(8), 1833-1842.

20. Devlin, M. F., Ray, A., Raine, P., Bowman, A. and Ayoub, A. F. 2007. Facial symmetry in unilateral cleft lip and palate following alar base augmentation with bone graft: a three-dimensional assessment. The Cleft Palate-Craniofacial Journal. 44(4), 391-395.

21. Duffy, S., Noar, J. H., Evans, R. D. and Sanders, R. 2000. Three-dimensional analysis of the child cleft face. The Cleft Palate-Craniofacial Journal. 37(2), 137-144.

22. Dusková, M., Kristen, M., Hronková, K. and Rákosník, P. 2002. Rhinomanometry in patients with a cleft deformity of the nose. Acta Chirurgiae Plasticae. 44, 124-128.

23. Farkas, L. G., Hajnis, K. and Posnick, J. C. 1993. Anthropometric and anthroposcopic findings of the nasal and facial region in cleft patients before and after primary lip and palate repair. The Cleft Palate-Craniofacial Journal. 30(1), 1-12.

24. Ferrario, V. F., Sforza, C., Dellavia, C., Tartaglia, G. M., Sozzi, D. and Carù, A. 2003. A quantitative three-dimensional assessment of abnormal variations in facial soft tissues of adult patients with cleft lip and palate. The Cleft Palate-Craniofacial Journal. 40(5), 544-549.

25. Fudalej, P., Katsaros, C., Hozyasz, K., Borstlap, W. A. and Kuijpers-Jagtman, A. M. 2012. Nasolabial symmetry and aesthetics in children with complete unilateral cleft lip and palate. The British Journal of Oral \& Maxillofacial Surgery. 50(7), 621-625.

26. Fukushiro, A. P. and Trindade, I. E. K. 2005. Nasal airway dimensions of adults with cleft lip and palate: differences among cleft types. The Cleft Palate-Craniofacial Journal. 42, 396-402.

27. Gosain, A. K. and Fathi, A. H. 2009. Assessment of secondary cleft rhinoplasty using resorbable plates at the age of primary school. The Journal of Craniofacial Surgery. 20(2), 1801-1805.

28. Guyuron, B. 2008. MOC-PS(SM) CME article: late cleft lip nasal deformity. Plastic and Reconstructive Surgery. 121, 1-11.

29. He, Z. J., Jian, X., Wu, X., Gao, X., Zhou, S. and Zhong, X. 2009. Anthropometric measurement and analysis of the external nasal soft tissue in 119 young Han Chinese adults. The Journal of Craniofacial Surgery. 20, 1347-1351.

30. Hood, C. A., Bock, M., Hosey, M. T., Bowman, A. and Ayoub, A. F. 2003. Facial asymmetry-3D assessment of infants with cleft lip \& palate. International Journal of Paediatric Dentistry. 13, 404-410. 
31. Hood, C. A., Hosey, M. T., Bock, M., White, J., Ray, A. and Ayoub, A. F. 2004. Facial characterization of infants with cleft lip and palate using a three-dimensional capture technique. The Cleft Palate-Craniofacial Journal. 41(1), 27-35.

32. Huempfner-Hierl, H., Hemprich, A. and Hierl, T. 2009. Results of a prospective anthropometric and functional study about aesthetics and nasal respiration after secondary rhinoplasty in cleft lip and palate patients. The Journal of Craniofacial Surgery. 20(2), 1863-1875.

33. Kim, S. K., Cha, B. H., Lee, K. C. and Park, J. M. 2004. Primary correction of unilateral cleft lip nasal deformity in Asian patients: anthropometric evaluation. Plastic and Reconstructive Surgery. 114(6), 1373-1381.

34. Kim, S. K., Heo, G. E., Seo, A., Na, Y. and Chung, S. K. 2014. Correlation between nasal airflow characteristics and clinical relevance of nasal septal deviation to nasal airway obstruction. Respiratory Physiology \& Neurobiology. 192, 95-101.

35. Kyrkanides, S., Bellohusen, R. and Subtelny, J. D. 1996. Asymmetries of the upper lip and nose in noncleft and postsurgical unilateral cleft lip and palate individuals. The Cleft Palate-Craniofacial Journal. 33(4), 306-311.

36. Krasone, K., Lace, B., Akota, I., Care, R., Deeley, K., Küchler, E. C. and Vieira, A. R. 2014. IRF6 AP-2a binding site promoter polymorphism is associated with oral clefts in Latvia. Stomatologija. 16(4), 132-136.

37. Kunkel, M., Wahlmann, U. and Wagner, W. 1997. Nasal airway in cleft-palate patients: acoustic rhinometric data. Journal of Cranio-Maxillo-Facial Surgery. 25(5), 270-274.

38. Landis, J. R. and Koch, G. G. 1977. An application of hierarchical kappa-type statistics in the assessment of majority agreement among multiple observers. Biometrics. 33(2), 363-374.

39. Li, C., Shi, B., He, X. and Meng, T. 2010. Evaluation of facial growth in non-cleft patients using the analysis method for patients after a cleft lip and/or palate repair. Journal of Plastic, Reconstructive \& Aesthetic Surgery. 63(2), 277-281.

40. van Loon, B., Maal, T. J., Plooij, J. M., Ingels, K. J., Borstlap, W. A., KuijpersJagtman, A. M., Spauwen, P. H. and Bergé, S. J. 2010. 3D Stereophotogrammetric assessment of pre- and postoperative volumetric changes in the cleft lip and palate nose. International Journal of Oral and Maxillofacial Surgery. 39(6), 534-540.

41. Lorot-Marchand, A., Guerreschi, P., Pellerin, P., Martinot, V., Gbaguidi, C. C., Neiva, C., Devauchelle, B., Frochisse, C., Poli-Merol, M. L. and Francois-Fiquet, C. 2015. Frequency and socio-psychological impact of taunting in school-age patients with cleft lip-palate surgical repair. International Journal of Pediatric Otorhinolaryngology. 79(7), 1041-1048.

42. Lu, K. H. 1965. Harmonic analysis of the human face. Biometrics. 21, 491-505.

43. Mani, M., Morén, S., Thorvardsson, O., Jakobsson, O., Skoog, V. and Holmström, M. 2010. EDITOR'S CHOICE: objective assessment of the nasal airway in unilateral cleft lip and palate--a long-term study. The Cleft Palate-Craniofacial Journal. 47(3), 217-224.

44. McComb, H. K. and Coghlan, B. A. 1996. Primary repair of the unilateral cleft lip nose: completion of a longitudinal study. The Cleft Palate-Craniofacial Journal. 33(1), 23-31. 
45. Meazzini, M. C., Rossetti, G., Morabito, A., Garattini, G. and Brusati, R. 2010. Photometric evaluation of bilateral cleft lip and palate patients after primary columella lengthening. The Cleft Palate-Craniofacial Journal. 47(1), 58-65.

46. Mercado, A., Russell, K., Hathaway, R., Daskalogiannakis, J., Sadek, H., Long, R. E. Jr., Cohen, M., Semb, G. and Shaw, W. 2011. The americleft study: an inter-center study of treatment outcomes for patients with unilateral cleft lip and palate part 4 . Nasolabial aesthetics. The Cleft Palate-Craniofacial Journal. 48, 259-264.

47. Millard, D. R. Jr. 1976. Cleft Craft: The Evolution of Its Surgery-Volume I: The Unilateral Deformity. Boston: Little Brown and Company.

48. Miyamoto, J., Miyamoto, S., Nagasao, T., Nakajima, T. and Kishi, K. 2012. Anthropometric evaluation of bilateral cleft lip nose with cone beam computed tomography in early childhood: Estimation of nasal tip collapse. Journal of Plastic, Reconstructive and Aesthetic Surgery. 65(2), 169-174.

49. Miyamoto, J. and Nakajima, T. 2010. Anthropometric evaluation of complete unilateral cleft lip nose with cone beam CT in early childhood. Journal of Plastic, Reconstructive and Aesthetic Surgery. 63(1), 9-14.

50. Mishima, K., Mori, Y., Yamada, T. and Sugahara, T. 2002. Anthropometric analysis of the nose in the Japanese. Cells, Tissues, Organs. 170(2-3), 198-206.

51. Mori, A., Nakajima, T., Kaneko, T., Sakuma, H. and Aoki, Y. 2005. Analysis of 109 Japanese children's lip and nose shapes using 3-dimensional digitizer. British Journal of Plastic Surgery. 58(3), 318-329.

52. Nolst Trenité, G. J., Paping, R. H. and Trenning, A. H. 1997. Rhinoplasty in the cleft lip patient. The Cleft Palate-Craniofacial Journal. 34, 63-68.

53. Okawachi, T., Nozoe, E., Nishihara, K. and Nakamura, N. 2011. 3-Dimensional Analyses of Outcomes Following Secondary Treatment of Unilateral Cleft Lip Nose Deformity. Journal of Oral and Maxillofacial Surgery. 69(2), 322-332.

54. Oosterkamp, B. C. M., Dijkstra, P. U., Remmelink, H. J., van Oort, R. P., GoorhuisBrouwer, S. M., Sandham, A. and de Bont, L. G. M. 2007. Satisfaction with treatment outcome in bilateral cleft lip and palate patients. International Journal of Oral and Maxillofacial Surgery. 36, 890-895.

55. Othman, S. A., Ahmad, R., Asi, S. M., Ismail, N. H. and Rahman, Z. A. A. 2014. Three-dimensional quantitative evaluation of facial morphology in adults with unilateral cleft lip and palate, and patients without clefts. The British Journal of Oral \& Maxillofacial Surgery. 52(3), 208-213.

56. Oti, A. A., Obiri-Yeboah, S. and Donkor, P. 2014. Aesthetic outcome and the need for revision of unilateral cleft lip repair at Komfo Anokye Teaching Hospital. Ghana Medical Journal. 48(1), 20-23.

57. Peck, H. and Peck, S. 1970. A concept of facial esthetics. Angle Orthodontist. 40(4), 284-318.

58. Peterka, M., Peterková, R., Tvrdek, M., Kuderová, J. and Likovský, Z. 2000. Significant differences in the incidence of orofacial clefts in fifty-two Czech districts between 1983 and 1997. Acta Chirurgiae Plasticae. 42, 124-129.

59. Pigott, R. W. and Pigott, B. B. 2010. Quantitative measurement of symmetry from photographs following surgery for unilateral cleft lip and palate. The Cleft PalateCraniofacial Journal. 47(4), 363-367. 
60. Pitak-Arnnop, P., Hemprich, A., Dhanuthai, K., Yildirim, V. and Pausch, N. C. 2011. Panel and patient perceptions of nasal aesthetics after secondary cleft rhinoplasty with versus without columellar grafting. Journal of Cranio-Maxillo-Facial Surgery. 39(5), 319-325.

61. Reiser, E., Andlin-Sobocki, A., Mani, M. and Holmström, M. 2011. Initial size of cleft does not correlate with size and function of nasal airway in adults with unilateral cleft lip and palate. Journal of Plastic Surgery and Hand Surgery. 45(3), 129-135.

62. Ridgway, E. B., Andrews, B. T., Labrie, R. A., Padwa, B. L. and Mulliken, J. B. 2011. Positioning the caudal septum during primary repair of unilateral cleft lip. The Journal of Craniofacial Surgery. 22, 1219-1224.

63. Russell, J. H. B., Kiddy, H. C. and Mercer, N. S. 2014. The use of SymNose for quantitative assessment of lip symmetry following repair of complete bilateral cleft lip and palate. Journal of Cranio-Maxillo-Facial Surgery. 42(5), 454-459.

64. Russell, K. A., Milne, A. D., Varma, D., Josephson, K. and Lee, J. M. 2011. Threedimensional morphologic nasal surface characteristics that predict the extremes of esthetics in patients with repaired cleft lip and palate. The Cleft Palate-Craniofacial Journal. 48(1), 28-37.

65. Russell, K. A., Waldman, S. D. and Lee, J. M. 2000. Video-imaging assessment of nasal morphology in individuals with complete unilateral cleft lip and palate. The Cleft Palate-Craniofacial Journal. 37(6), 542-550.

66. Russell, K. A., Waldman, S. D., Tompson, B. and Lee, J. M. 2001. Nasal morphology and shape parameters as predictors of nasal esthetics in individuals with complete unilateral cleft lip and palate. The Cleft Palate-Craniofacial Journal. 38(5), 476-485.

67. Russell, K., Orthod, D., Tompson, B. and Paedo, D. 2009. Correlation between facial morphology and esthetics in patients with repaired complete unilateral cleft lip and palate. The Cleft Palate-Craniofacial Journal. 46(3), 319-325.

68. Sandham, A. and Murray, J. A. 1993. Nasal septal deformity in unilateral cleft lip and palate. The Cleft Palate-Craniofacial Journal. 30, 222-226.

69. Shaw, W. C., Semb, G., Nelson, P., Brattstrom, V., Molsted, K., Prahl-Andersen, B. and Gundlach, K. K. H. 2001. The Eurocleft Project 1996-2000: overview. Journal of Cranio-Maxillofacial Surgery. 29(3), 131-140.

70. Sinko, K., Jagsch, R., Prechtl, V., Watzinger, F., Hollmann, K. and Baumann, A. 2005. Evaluation of esthetic, functional, and quality-of-life outcome in adult cleft lip and palate patients. The Cleft Palate-Craniofacial Journal. 42(4), 355-361.

71. Stauber, I., Vairaktaris, E., Holst, A., Schuster, M., Hirschfelder, U., Neukam, F. W. and Nkenke, E. 2008. Three-dimensional analysis of facial symmetry in cleft lip and palate patients using optical surface data. Journal of Orofacial Orthopedics. 69(4), 268-282.

72. Stebel, A., Desmedt, D., Bronkhorst, E., Kuijpers, M. A. and Fudalej, P. S. 2016. Rating nasolabial appearance on three-dimensional images in cleft lip and palate: a comparison with standard photographs. European Journal of Orthodontics. 38(2), 197-201.

73. Torre, J. I., Gallagher, P. M., Douglas, B. K. and Tenenhaus, M. 2000. Repairing the Cleft Lip Nasal Deformity. The Cleft Palate-Craniofacial Journal. 37(3), 234-242. 
74. Trindade, I. E. K., Bertier, C. E. and Sampaio-Teixeira, A. C. M. 2009. Objective assessment of internal nasal dimensions and speech resonance in individuals with repaired unilateral cleft lip and palate after rhinoseptoplasty. The Journal of Craniofacial Surgery. 20(2), 308-314.

75. Trotman, C. A., Faraway, J. J., Losken, H. W. and van Aalst, J. A. 2007. Functional outcomes of cleft lip surgery. Part II: Quantification of nasolabial movement. The Cleft Palate-Craniofacial Journal. 44(6), 607-616.

76. Verzé, L., Bianchi, F. A. and Ramieri, G. 2014. Three-dimensional laser scanner evaluation of facial soft tissue changes after LeFort I advancement and rhinoplasty surgery: patients with cleft lip and palate vs patients with nonclefted maxillary retrognathic dysplasia (control group). Oral Surgery, Oral Medicine, Oral Pathology and Oral Radiology. 117(4), 416-423.

77. Weinberg, S. M., Naidoo, S. D., Bardi, K. M., Brandon, C. A, Neiswanger, K., Resick, J. M., Martin, R. A. and Marazita, M. L. 2009. Face shape of unaffected parents with cleft affected offspring: combining three-dimensional surface imaging and geometric morphometrics. Orthodontics \& Craniofacial Research. 12(4), 271-281.

78. Wu, J., Liang, S., Shapiro, L. and Tse, R. 2016. Measuring Symmetry in Children With Cleft Lip. Part 2: Quantification of Nasolabial Symmetry Before and After Cleft Lip Repair. The Cleft Palate-Craniofacial Journal. 53(6), 705-713.

79. Yamada, T., Mori, Y., Minami, K., Mishima, K., Sugahara, T. and Sakuda, M. 1999. Computer aided three-dimensional analysis of nostril forms: application in normal and operated cleft lip patients. Journal of Cranio-Maxillo-Facial Surgery. 27, 345-353.

80. Yamada, T., Mori, Y., Minami, K., Mishima, K. and Tsukamoto, Y. 2002. Surgical results of primary lip repair using the triangular flap method for the treatment of complete unilateral cleft lip and palate: a three-dimensional study in infants to fouryear-old children. The Cleft Palate-Craniofacial Journal. 39(5), 497-502.

81. Zaleckas, L., Linkevičienè, L., Olekas, J. and Kutra, N. 2011. The Comparison of Different Surgical Techniques Used for Repair of Complete Unilateral Cleft Lip. Medicina (Kaunas). 47(2), 85-90.

82. Zreaqat, M., Hassan, R. and Halim, A. S. 2012. Facial dimensions of Malay children with repaired unilateral cleft lip and palate: a three dimensional analysis. International Journal of Oral and Maxillofacial Surgery. 41(6), 783-788.

83. Баркане, Б. Я. 1968. Оперативное лечение деформаций губы и носа при врожденных расщелинах лица: Диссертация на соискание учен. степени канд. мед. наук. Рига. 328 с. 


\section{PUBLIKĀCIJAS UN ZIN̦OJUMI PAR PĒTĪJUMA TĒMU}

\section{Publikācijas starptautiski citējamos zinātniskos izdevumos}

1. Bagante, I. and Akota, I. 2015. Cleft-related nose deformation evaluation and measurement methods. Literature review. Stomatologija. 17(3), 75-83.

2. Bagante, I., Zepa, I. and Akota, I. 2018. 3D Assessment of nasolabial appearance in patients with complete unilateral cleft lip and palate. The Cleft Palate-Craniofacial Journal. 55(2), 220-225.

\section{Publikācijas Latvijā citējamos zinātniskos izdevumos}

1. Bāgante, I. un Akota, I. 2013. Deguna estētikas novērtējums pacientiem ar vienpusēju caurejošu lūpas, alveolārā izauguma un aukslēju šķeltni. $R S U$ Zinātniskie raksti. 421-427.

2. Bāgante, I. un Akota, I. 2014. Deguna elpošanas funkcijas salīdzinājums starp pacientiem ar vienpusēju caurejošu lūpas, alveolārā izauguma un aukslēju šķeltni un kontroles grupu. RSU Zinātniskie raksti. 340-344.

\section{Mutiskās prezentācijas starptautiskās zinātniskajās konferencēs}

1. Bagante I., Akota I., Barkane B. The Nose appearance in patients with unilateral complete cleft lip and palate. 11th Joint Symposium Rostock - Riga. Rostoka, Vācija, 04-05.05.2012.

2. Bagante I., Akota I., Barkane B. Эстетическая оценка первичной коррекции носа у детей с односторонней сквозной расщелиной губы, альвеолярного отростка и нёба. 17. Starptautiskais sejas un žokḷu ķirurgu un zobārstu kongress. Pēterburga, Krievija 15-17.05.2012, tēzes 20-21. lpp.

3. Bagante I., Akota I. The nasal function in patients with complete unilateral cleft lip and palate. 21.Internacionālā mutes sejas un žokḷu ķirurğijas konference. Barselona, Spānija 21-24.10.2013, tēzes - International Journal of Oral and Maxillofacial surgery, Vol 42, Issue 10, 2013, Oct, 1194.lpp.

4. Akota I., Bagante I. Cleft treatment in Riga cleft Lip and Palate Centre. Symposium "Challenges in the treatment of cleft lip and palate", Bukareste, Rumānija 31.03-02.04.2014.

5. Bagante I., Akota I. The nasal function in patients with complete unilateral cleft lip and palate and control group. 12. Joint Symposium Rostock - Riga Rīga, Latvija 09-10.05.2014, tēzes 61-62.lpp. 
6. Bagante I., Akota I., Bitans E. The 3D Nasolabial Evaluation in Cleft Patients. IADR/PER congress, Dubrovņiki, Horvātija 10.-13.09.2014, tēzes nr. S 0584. (https://live.blueskybroadcast.com).

7. Bagante I., Akota I., Bitans E. The three-dimensional nasolabial appearance in patients with complete unilateral cleft lip and palate. XXII Congress of the European Association for Cranio-Maxillo-Facial Surgery, Prāga, Čehija 23.-26.09.2014, tēzes nr. 0-0505, 95. Lpp.

8. Bagante I., Zepa I., Akota I. Nasal function and nasolabial appearance in patients with unilateral complete cleft lip, alveolus and palate in Riga Cleft Lip and Palate Centre. 10th European Craniofacial Congress, Gēteburga, Zviedrija 24-27.06.2015, tēzes nr. 3363.

9. Zepa I., Bagante I., Akota I. Facial growth results in patients with nonsyndromic complete UCLP treated with one-stage and two-stage palatal repair. 10th European Craniofacial Congress, Gēteburga, Zviedrija 24-27.06.2015, tēzes nr. 2231.

10. Bagante I., Akota I. Nasal function and 3D appearance in patients with unilateral complete cleft lip, alveolus and palate in Riga Cleft Lip and Palate Centre. 13th Joint Symposium Riga-Rostock, Rostoka, Vācija 5-7.05.2016.

11. Bagante I., Akota I. Nasal Function and 3D nasal appearance in patients with clefts and control group. 9. Baltijas sejas, žokḷu un plastiskās ķirurǵijas kongress (BAMPS), Tartu, Igaunija 12-13.05.2017, tēzes 19. Lpp.

\section{Mutiskās prezentācijas Latvijas zinātniskajās konferencēs}

1. Bāgante I., Akota I. Deguna estētikas novērtējuma metodes aprobācija bērniem ar vienpusējām caurejošām lūpas, alveolārā izauguma un aukslēju šķeltnēm. Rezidentu XIV zinātniski - praktiskā konference „Aktualitātes medicīnā", Rīga, Latvija 08.06.2011.

2. Bāgante I., Akota I. Deguna elpošanas funkcija pacientiem ar vienpusēju caurejošu lūpas, alveolārā izauguma un aukslēju šḳeltni. RSU 12. zinātniskā konference, Rīga, Latvija 21-22.03.2013, tēzes 298.lpp.

3. Bāgante I., Akota I., Bitāns E. Deguna un lūpas novērtējums pacientiem ar vienpusēju caurejošu lūpas, alveolārā izauguma un aukslēju šķeltni. RSU 13. zinātniskā conference, Rīga, Latvija 10-11.04.2014, tēzes 321.lpp.

4. Bāgante I., Akota I., Zepa I. Deguna elpošanas funkcija un simetrija pacientiem ar vienpusēju caurejošu lūpas, alveolārā izauguma un aukslēju šķeltni. RSU 14. zinātniskā konference, Rīga, Latvija 26-27.03.2015, tēzes 301.lpp.

5. Bāgante I., Akota I. Deguna simetrijas un elpošanas funkcijas novērtējums pacientiem ar iedzimtām šķeltnēm, salīdzinot ar kontroles grupu. RSU 16. zinātniskā konference, Rīga, Latvija 6-7.04.2017, tēzes 32.lpp. 
6. Bāgante I., Akota I. Deguna elpošanas funkcija un simetrija bērniem ar vienpusēju caurejošu lūpas, alveolārā izauguma un aukslēju šķeltni. 8. Latvijas Ārstu kongress, Rịga, Latvija 21.-23.09.2017.

\section{Stenda referāti starptautiskās zinātniskajās konferencēs}

1. Bagante I., Akota I., Barkane B. The nasal correction in the patients with unilateral complete cleft lip and palate. 10th Joint Symposium RostockRiga,Riga, Latvia, 07.-10.05.2009, tēzes Stomatologija, Baltic Dental and Maxillofacial Journal (2009), Suppl.6 23.lpp.

2. Bagante I., Akota I., Barkane B. The nose assesment methodology in patients with unilateral complete cleft lip and palate. 7. Baltijas sejas, žokḷu un plastiskās ķirurğijas kongress, Riga, Latvia 20.-22.05.2010, tēzes 63-64.lpp.

3. Bagante I., Akota I., Klimecs V. Rhinomanometry in patients with unilateral complete cleft lip and palate in Riga Cleft Lip and Palate Centre. 8. Baltijas sejas, žokḷu un plastiskās k̦irurğijas kongress (BAMPS), Kauņa, Lietuva 10.-11.05.2013, tēzes 46-47.1pp.

4. Bagante I., Akota I. Results of rhinomanometric investigation in patients with unilateral complete cleft lip and palate. 2nd International Medical Meeting 17th LDVA congress, Riga, Latvia 14-15.06.2013, tēzes 43.lpp.

5. Akota I., Bagante I. The 3D nasal appearance in patients with complete unilateral cleft lip and palate. $23^{\text {rd }}$ Congress of the European association for Cranio Maxillo-Facial Surgery (EACMF), Londona, Lielbritānija 13-16.09.2016, tēzes 52.lpp, nr. 0825.

\section{Stenda referāti Latvijas zinātniskajās konferencēs}

1. Bāgante I., Akota I. Primāra un sekundāra deguna korekcija pacientiem ar vienpusēju caurejošu lūpas, alveolārā izauguma un aukslēju šķeltni. RSU 8. zinātniskā konference, Rīga, Latvija 02.-03.04.2009, tēzes, 209.lpp.

2. Bāgante I., Akota I., Barkāne B. Primāra deguna korekcija pacientiem ar vienpusēju caurejošu lūpas, alveolārā izauguma un aukslēju šķeltni. RSU 9. zinātniskā konference, Rīga, Latvija 18.-19.03.2010, tēzes, 307.lpp.

3. Bāgante I., Akota I. Deguna novērtējums pēc plastiskajām operācijām trīs dimensiju (3d) attēlos. RSU 15. Zinātniskā konference. Rīga, Latvija 17-18.03.2016, tēzes 217.lpp. 


\section{PATEICĪBAS}

Vēlos izteikt pateicību savai darba vadītājai profesorei Ilzei Akotai, bez kuras palīdzības un zināšanām šis darbs nebūtu iespējams. Paldies par ieguldīto laiku, vērtīgiem padomiem un par piedalīšanos deguna estētikas novērtēšanā 2D fotoattēlos.

Īpašs paldies Elvisam Railijam Bitānam par ieguldīto laiku un palīdzību datu ievākšanas procesā kopīgi apgūstot jaunās tehnolog̣ijas.

Paldies manai mịlajai kolēǵei Inai Freimanei par sapratni un pacietību darba tapšanas laikā un par dalību deguna estētikas novērtēšanā 2D fotoattēlos.

Paldies Ievai Greitānei par ieguldīto laiku un palīdzību gan materiālu vākšanā, sagatavošanā, gan piedaloties deguna estētikas novērtēšanā 2D fotoattēlos.

Paldies profesorei Ilgai Urtānei par atsaucību un iespēju veikt darbu RSU Stomatologijas institūtā.

Paldies Irēnai Rogovskai par palīdzību statistikas jautājumos.

Paldies darba recenzentiem profesoram Aigaram Pētersonam un profesorei Rūtai Carei par ieguldīto laiku darba recenzēšanā.

Paldies maniem bērniem, vīra vecākiem un īpaši vīram Oskaram par izturību, sapratni, uzmundrinājumiem un ticību maniem spēkiem š̄ darba tapšanas laikā.

Bet vislielākais paldies manai mịlajai mammai, bez kuras, šis darbs nebūtu iespējams, paldies par palīdzību gan tiešā, gan netiešā veidā. Paldies par izturību, sapratni un ieguldīto laiku.

Paldies visiem, kurus šeit nepieminēju, bet kuri ir man palīdzējuši un atbalstījuši darba tapšanas gaitā. 